\title{
The effect of the use of systematic teaching method Viyolonsel eğitimi sürecinde on students' success in the dizgeli öğretim modelinin process of violoncello öğrenci başarısına etkisi education $^{1}$
}

\author{
Çağñ Şen ${ }^{2}$ \\ Mehmet Ali Özdemir ${ }^{3}$
}

\section{Abstract}

This study was conducted to examine the effect of the use of systematic teaching method in fine arts high school violoncello education lessons on students' academic success in terms of cognitive and psychomotor skills. In this study, the pretest-posttest control group experimental pattern was used. The study was carried out with a sample of 14 violoncello students studying at Bursa Zeki Müren Fine Arts High School, 7 in the experimental group and 7 in the control group. In the scope of this study, a syllabus for 8 weeks (16 hours) was prepared based on systematic teaching method so as to improve the cognitive and psychomotor learning levels of the students. In order to gain the data, two scales were developed by the researcher aimed at cognitive field and psychomotor field. Whereas the experimental group was applied a syllabus based on systematic teaching for 8 weeks, the control group was applied the traditional method which was being used at school. The data obtained from pretest and posttest were analyzed with statistical methods. In accordance with the data

\section{Özet}

$\mathrm{Bu}$ araştırmada, güzel sanatlar liselerinde dizgeli ögretim modeline göre yapılandırılmış viyolonsel eğitimi dersinin, bilgi düzeyi ve performansa ilişkin beceriler bakımından öğrencilerin akademik başarılarına etkisini belirlemek amaçlanmıştır. Öntest-sontest kontrol gruplu deneysel desene uygun düzenlenen araştırmanın örneklemini, Bursa Zeki Müren Güzel Sanatlar Lisesi'nde öğrenim gören, deney grubunda 7 ve kontrol grubunda 7 olmak üzere 14 viyolonsel öğrencisi oluşturmuştur. Viyolonsel öğrencilerinin bilgi düzeylerini ve performansa yönelik beceri düzeylerini arttrmak amaciyla, dizgeli öğretim modeline dayalı 8 haftalık (16 ders saati) süreyi kapsayan ders planı hazırlanmıştur. Araştırma verilerini elde etmek üzere, bilişsel ve devinişsel alana yönelik iki tür ölçek geliştirilmiştir. 8 hafta süreyle deney grubuna dizgeli öğretim modeline dayalı viyolonsel eğitimi uygulanırken, kontrol grubunda geleneksel öğretim sürdürülmüsstür. Öntest ve sontestten elde edilen veriler istatistiksel analizlerle çözümlenmiştir. Araştırmadan elde edilen bulgular şöyle

\footnotetext{
1 This study is based on a doctoral dissertation titled "The Effect of the Use of Systematic Teaching Method on Students' Success in Fine Arts and Sports High School Violoncello Education Lessons" which was accepted in December 2012.

2 Ph.D., MEB (Ministry of National Education), Music Teacher, Bursa, cagrisen16@gmail.com

3 Assoc. Prof. Dr., Marmara University, Atatürk Faculty of Education, Department of Music Teacher Education, maliozdemir2001@yahoo.com
} 
Şen, C.., \& Özdemir, M. A. (2017). Viyolonsel eğitimi sürecinde dizgeli öğretim modelinin öğrenci başarısına etkisi. Journal of Human Sciences, 14(4), 3009-3029. doi:10.14687/jhs.v14i4.4881

gained from the research, the findings can be summarized as the following: A meaningful difference in favour of the experimental group was found between experimental group to which systematic teaching method was applied and the control group to which traditional method was applied in terms of both the knowledge level and the skill level of performance.

Keywords: Fine arts high school; instrument education; violoncello education; systematic teaching; success; performance; skill.

(Extended English abstract is at the end of this document) özetlenebilir: Dizgeli öğretim modelinin uygulandığ1 deney grubu ile geleneksel öğretim yapilan kontrol grubu arasında, hem bilgi düzeyi hem de performansa ilişkin beceri düzeyi bakımından deney grubu lehine anlamlı farklılık bulunmuştur.

Anahtar Kelimeler: Güzel sanatlar lisesi; çalg1 eğitimi; viyolonsel eğitimi; dizgeli öğretim modeli; başarn; performans; beceri.

\section{Giriş}

Eğitim, insanın kalıtsal güçlerinin geliştirilerek istenen özelliklerle donatılmış bir kişiliğe kavuşturulması sürecidir. Bu süreç, birbiri ile iç içe geçmiş öğretme ve öğrenme etkinlikleri ile gerçekleştirilir. Öğretme, öğrenmeyi sağlama ve rehberlik etme etkinliği; öğretim ise planlı ve programlı öğretme etkinlikleridir. Öğretme etkinliklerinin nitelikli şekilde planlanması, öğretim sürecinin başarısını getirir (Fidan, 1996: 10; Varış, 1998: 1; Senemoğlu, 2007: 398). Bu doğrultuda öğretim faaliyetlerinin düzenlenmesi, yürütülmesi ve değerlendirilmesiyle ilgili evreler ve gerekli koşullar önceden tasarlanarak ve tespit edilerek öğretim planlı hale getirilmelidir. Öğretim programı ne ölçüde nitelikli planlanmış ve ders ne derecede nitelikli sunulmuş ise öğretimin niteliği de o derecede yükselir (Hesapçıŏlu, 1998: 36; Senemoğlu, 2007: 463).

Eğitimin alt alanlarından biri olan müzik eğitimi, bir müziksel davranış kazandırma veya bir müziksel davranış değişikliği oluşturma süreci olarak tanımlanabilir. Bu süreçte belirli hedefler doğrultusunda planlı ve belirli yöntemlere göre izlenecek yollar, kazandırılacak davranışların düzeyini belirler (Uçan, 1994: 14). Bu bakımdan, müzik eğitiminde davranış değişikliklerinin istenilen düzeyde gerçekleştirilebilmesi için müziksel öğrenme etkinliklerinin doğru planlanması ve uygulanması gereklidir (Kurtuldu, 2007: 1).

Müzik eğitiminin en temel alt boyutlarından birini oluşturan çalg1 eğitimi, özenli, sabırlı ve planlı çalışma gerektiren bir süreçtir. Bu sürecin niteliği, çalg1 eğitimcisinin çalg1 öğretimini kolaylaştırıc1 ve aşama kaydetmeyi sağlayıcı yöntemler geliştirerek öğrenme ilkelerinden ve öğretim yöntemlerinin uygulamalarından etkili biçimde yararlanmasına bağlıdır (Greer, 1980: 66; Özen, 2004: 59). Bunun yanında müzik eğitiminin geliştirilebilmesinin temelindeki yol gösterici ilkelerin başında, teori odaklı olma gerekliliği taşıyan ders planı bulunmaktadır (Hargreaves, 1999: 45-46). Bu bağlamda çalg1 eğitiminde ders planının hazırlayıcısı ve uygulayıcısı olan eğitmenlere büyük görevler düşmektedir. Çalg1 eğitimcileri, öğrencilerin müzikal gelişimi için öğretim yöntemleri geliştirerek uygun stratejiler belirlemeli, yol gösterici ve açıklayıcı bir çerçeve oluşturarak derslerini planlamalıdırlar.

Müzik eğitiminde bilişsel beceriler, müzikle ilgili bilgileri anlamayı, kavramayı, analiz etmeyi, tanımlamayı ve sentezlemeyi gerektiren zihinsel etkinliklerin tümünü kapsar. Sözü edilen bilişsel süreçler, çalg1 eğitiminde psiko-motor davranışların geliştirilmesinde önemli yer tutar. Bu nedenle, çalg1 çalma sırasında psiko-motor davranışların zihinsel bir süreçten geçtiği ve bilişsel bir içerikle beceriye dönüştüğü gerçeği unutulmamalıdır (Yokuş ve Yokuş, 2010: 17; Yağ1şan, 2008: 11-12). Buradan hareketle, çalg1 eğitiminde hedefler doğrultusunda istendik davranış değişiminin ve gelişiminin sağlanabilmesi ve dolayısıyla etkin öğrenmenin gerçekleşebilmesi için bilişsel süreçlerin dikkatle ele alınması gereklidir. 
Şen, C.., \& Özdemir, M. A. (2017). Viyolonsel eğitimi sürecinde dizgeli öğretim modelinin öğrenci başarısına etkisi. Journal of Human Sciences, 14(4), 3009-3029. doi:10.14687/jhs.v14i4.4881

Çalg1 eğitimi içerisinde önemli bir yere sahip olan viyolonsel, gerek teknik kapasite, gerek literatür ve gerekse müzikal ifade (yorum) bakımından oldukça geniş imkânlara sahip, mesleki müzik eğitiminde etkin biçimde kullanılabilen bir eğitim aracıdır (Demirbatır, 1996: 159). Viyolonsel eğitiminde öğrencilerin müzikal düşünce ve algiları geliştirilerek müzik eğitimini tüm alt alanları ile bir bütün olarak görmeleri, bilişsel, duyuşsal ve psiko-motor alanlara yönelik davranışlar kazanmaları amaçlanmaktadır (Otacıoğlu, 2005: 8). Kleesattel (2012: 1, 8)'a göre de viyolonsel çalıcılanı, müziği algılamak ve müzik yapmak için akıllarını ve bedenlerini kullanmak, etkili çalma yeteneğine sahip olmak için ise zihin ve bedenin çeşitli becerilerini geliştirmek ve yetiştirmek zorundadırlar.

Viyolonsel eğitiminde genel olarak hedeflenen davranışlar şu başlıklar altında toplanabilir: Duruş ve tutuş, çalğda teknik hâkimiyet, tempo ve ritim, entonasyon, artikülasyon, dinamik öğeler, müzikal ifade ve kavramlar bilgisi. Bu başlıkları içeren davranışların kazandırılması için, planlanacak öğretim faaliyetlerinin belirli bir düzen içerisinde öğrenciye sunulması gereklidir. Bu düzenin sağlanamaması durumunda, viyolonsel eğitiminin bir yönünün aksayacağ1 söylenebilir. $\mathrm{Bu}$ doğrultuda, viyolonsel eğitimi sürecinde uygulanacak her türlü öğretim etkinliğinin hedefleri ve işleyişi öğretmen tarafindan bilinçli bir şekilde tanımlanarak öğrenciye hissettirilmeli ve bu yönde yine bilinçli bir şekilde belirlenmiş öğretim materyalleri (gam, etüt, eser, vb.) ile bu eğitim sistemli bir şekilde sürdürülmelidir.

Çalg1 eğitimi belirli bir zaman diliminde gerçekleştirilse de bu süreç, çalıcılar için yaşam boyu devam eden ve sürekli yenilenen bir yapıdadır. Bu nedenle, çalg1 eğitimi sürecinde bireylerin yeni bilgileri önceki öğrenmelerine dayalı olarak kendi başlarına anlamlı hale getirebilmeleri önemlidir. Bu durum çalg1 eğitimi sürecinde öğreticilere, bireylere kendi öğrenmelerini planlamak üzere yol gösterici olma anlamında sorumluluk yüklemektedir. Saraç (2003: 13)'a göre de viyolonsel eğitimcileri, işlenecek konular ve içerik ile öğretim yöntem ve teknikleri arasında düzeni ve gerekli uyumu sağlayabilmeli, dersleri buna göre planlayarak yürütmelidir. Doğru şekilde kurulan bu bağlantı ve eşgüdüm sayesinde viyolonsel dersinin öğretme-öğrenme süreci, başı ve sonu belli olan ve sürekli iyileştirme dönütleriyle kontrol edilebilen bir sistem haline gelmiş olur.

Eğitimin diğer alanlarında olduğu gibi çalg1 eğitimi sürecinde de öğrenmeyi daha etkili ve verimli kılmak amacıyla farklı öğretme modellerinden yararlanılmaktadır. Sözü edilen bu öğretme modelleri, etkili öğrenmenin gerçekleștirilmesinde öğrenme düzeyini etkileyen önemli değișkenleri ve bunlar arasındaki ilişkileri açılamaktadır. Bununla birlikte öğretme modelleri incelendiğinde, modellerin ana değişkenlerinin birbirine benzer nitelikte olduğu görülebilir (Senemoğlu, 2007: 430). Bilişsel, duyuşsal ve devinişsel davranışların karmaşık bir örüntüsü olarak kendine özgü nitelikleri bakımından çalgı eğitimi süreci ele alındığında, çeşitli kuram, strateji, yöntem ve tekniklerin bir arada kullanımına olanak tanıyan bir modelin uygulanması ihtiyacından söz edilebilir. Çalg1 eğitiminin bireysel olması ve bireysel farklılıklar doğrultusunda şekillendirilmesi gereği ile bu ihtiyacın arttı̆̆1 söylenebilir.

Buraya kadar açıklananlar doğrultusunda, içerik bakımından eğitim biliminin ilkelerine göre belirlenmiş yapısıyla, öğretimin her basamağının planlandığı dizge yaklaşımı sayesinde dersi işlemede öğretmene ve hedef davranışlanı öğrenmede öğrencilere kolaylık sağladığı düşünülen dizgeli (programlandırılmış) öğretim modelinin viyolonsel eğitimi sürecinde uygulanarak viyolonsel eğitiminin niteliğinin arttırılmasına katkı sağlayabileceği düşüncesi doğmuştur.

\subsection{Dizgeli öğretim}

Sönmez (2004: 1) tarafindan 1982 yllında geliştirilen dizgeli öğretim modeli, eğitimin çeşitli alanlarında olmak üzere doktora ve yüksek lisans tezlerinde, bazı araştırmalarda, değişik okullarda ve derslerde denenmiştir. Dizgeli öğretim modeli, köy enstitüleri, tam öğrenme yaklaşımı, bilgiyi işleme süreci, bilgisayar destekli eğitim, olabilirlik felsefesi ve öğretmenlik uygulamalarının ve araştırmalarının bir sentezi yapılarak oluşturulmuştur.

Dizgeli (programlandırılmış) eğitim (öğretim) modeli, tüm kuram, strateji, yöntem ve tekniklerin yeri geldikçe işe koşulduğu, eğitimin sistem (dizge) yaklaşımına ve olabilirlik felsefesine göre 
Şen, Ç., \& Özdemir, M. A. (2017). Viyolonsel eğitimi sürecinde dizgeli öğretim modelinin öğrenci başarısına etkisi. Journal of Human Sciences, 14(4), 3009-3029. doi:10.14687/jhs.v14i4.4881

yapılandırılmasıyla oluşturulmuş, eğitim durumlanının bu anlayış doğrultusunda planlandığı ve üst düzeyde öğrenci katılımının amaçlandığ1 sentez bir modeldir (Eldemir, 2010: 31).

Dizgeli öğretimde, rehber konumunda olan öğretmen tarafindan öğrenme ve öğretme etkinliklerinin tümünde öğrenci temele alınır. Öğretmen, bilgiyi bularak keşfedebilmesi, anlamlandırabilmesi, kullanabilmesi ve yeniden yapılandırabilmesi için öğrenciye uygun ortamlar hazırlar ve olanaklar sunar (Yokuş, 2009b: 27-28).

Dizgeli eğitim modelinin temel ilkeleri şunlardır (Sönmez, 2004: 58):

1. Hiçbir kuram, öğrenme ve öğretmeyi tek başına tümüyle açıklayamamaktadır.

2. Her davranış yani bilişsel, duyuşsal, devinişsel, sezgisel özellikler, tek bir kuram, yöntem ve teknikle kişiye öğretilememektedir.

3. Her insan aynı davranışı aynı strateji, kuram, yöntem, teknik ve taktikle öğrenememektedir. Aynı davranışı öğrenmek ve öğretmek için her insan farklı yollar kullanabilmektedir. Çünkü insan hem birbirinden farklı, hem bazı özellikleri ile benzer, hem de çok boyutlu bir varlıktır.

4. İnsan tek bir etkinlikle öğrenememektedir. Pek çok etkinliği bir arada kullanınca davranışlar daha kalıcı olabilmektedir.

5. Davranışın düzeyi ve niteliği değissince farklı strateji, kuram, yöntem, teknik ve taktikler, akıl yürütme yolları işe koşulmalıdır.

6. Öğretimde ders değil ünite temele alınabilir. Bu ünitenin etrafinda Türkçe, resim, müzik, beden eğitimi vb. derslerin hedef davranışları kazandırılabilir.

7. Öğrenciye bilgiyi bulup çıkarma, anlama, kullanma ve yeniden üretip yaratma becerisi kazandırılabilir.

Alkan (1987: akt. Şahinkesen, 1990: 648) dizge yaklaşımının, eğitimde ilgililere problemleri ayırt etme ve belirleme, uygun stratejiler geliştirme ve genel olarak öğrenme-öğretme sistemi üzerinde bunların etkisini ve başarısını değerlendirme yeteneği kazandırdığını belirtmektedir.

Dizgeyi "en az bir hedefi gerçekleştirmek üzere uygun ve değişik öğelerden oluşan dirik bir örüntü” olarak tanımlayan Sönmez (2004: 4), eğitimin dizge (sistem) yaklaşımı göz önünde bulundurularak ele alınması gerektiğini savunmaktadır. Dizge yaklaşımıyla eğitimi denetlemenin, yenilemenin, düzeltmenin, işleyen yanları elde tutarak işlemeyenleri onarmanın, atmanın, yerine yenilerini koymanın daha kolay olduğunu vurgulamaktadır. Ĕ̆er birey, önceden planlanmış öğretim etkinliklerini izlerse kendisinden beklenen davranış değişiklikleri gerçekleşir. Çünkü öğrencide istendik davranışlar oluşturulacaksa bunun bir düzen içinde ona sunulması gerekmektedir. Eğitimde dizge yaklaşımı öğretmene dersi işlemede, öğrenciye ise hedef davranışlanı öğrenmede kolaylık sağlamaktadır. Dizgeli eğitim anlayışı ile bireyin kendini gerçekleştirerek yaratıcı düşünceler ortaya koymas1; bilgiyi, beceriyi, duyguyu ve sezgiyi bulması, anlamas1, kullanması ve sonunda ondan yenilerini üretmesi daha kolay gerçekleşmektedir.

Sönmez (1994: 136)'e göre, bir öğretim sürecinde davranışlar öğrenciye kazandırılırken aşamalı sıraya uyulmall; ipucu, düzeltme, dönüt ve pekiştireçler uygun yer ve zamanda kullanılmalı; öğrenci katılımı en üst düzeyde sağlanmalı; uygun öğrenme-öğretme stratejileri, yöntem ve teknikler ile akıl yürütmeler iç içe düzenlenmelidir. Dizgeli eğitimde tüm bu adımlar günlük ders planında ayrıntılı olarak gösterilmektedir.

Dizgeli öğretim modelinin etkililiğinin denendiği, buna göre ders planlanının düzenlenerek uygulandığ1 birçok araştırma bulunmaktadır. Bayazıtoğlu (1996), Kayabaş1 (1997), Öztürk (1997), Acat (1997), Eroğul (1997), Sıvacı (1997), Adıgüzel (1998), Altınok (1998), Kilıç (2000), Sönmez (2000), Alacapınar (2001), Emir (2001), Çetin (2003), Memişoğlu (2003), Sönmez (2003), Koçak (2004), Paş (2004), Kapıcıŏlu (2006), Küçükoğlu (2007), Takkaç (2007), Duman (2009), Öntaş (2010), Sezginsoy (2011), Aslan (2012), Durdukoca (2013), Özalemdar (2013), Toklucu (2013) ve Özdemir (2014) tarafindan yapılan çalışmalardan elde edilen bulgulara göre, dizgeli eğitim yaklaşımının bilişsel, duyuşsal ve devinişsel hedef davranışların kazandırılmasında etkili olduğu sonucuna varılmışır. 
Şen, Ç., \& Özdemir, M. A. (2017). Viyolonsel eğitimi sürecinde dizgeli öğretim modelinin öğrenci başarısına etkisi. Journal of Human Sciences, 14(4), 3009-3029. doi:10.14687/jhs.v14i4.4881

Dizgeli öğretim ile ilgili müzik ve çalg1 eğitimi alanında yapılmış araştırmalar (Otacıŏ̆lu, 2005; Piij, 2006; Yokuş, 2009a; Yokuş, 2009b; Eldemir, 2010; Küpana, 2011; Akgül, 2013; Özdemir, 2014) da bulunmaktadır. Ancak çalg1 eğitimi içerisinde viyolonsel eğitimine yönelik, dizgeli öğretimin denendiği bir çalışmaya rastlanmamıştır.

Müzik eğitiminin dallarından biri olan çalg1 eğitiminde öğretim yöntemlerinin etkililiğini araştırmaya yönelik çalışmalar, kuşkusuz daha verimli öğretme-öğrenme ortamlarının oluşturulmasına ve daha işlevsel nitelikte öğretim programlarının geliştirilmesine katkıda bulunacakttr. $\mathrm{Bu}$ düşüncelere paralel olarak viyolonsel eğitimi dersinin, öğretmen ve öğrenci açısından nasıl daha etkin hale getirilebileceği sorusu araştırmanın başlangıç noktasını oluşturmuştur. $\mathrm{Bu}$ doğrultuda dizgeli öğretim modeli temel alınarak viyolonsel eğitimi süreçlerindeki öğretim faaliyetlerinin planlandığı ve etkililiğinin denendiği bir araştırma yapılmıştır.

\section{Araştırmanın amacı ve önemi}

$\mathrm{Bu}$ araştırma, dizgeli eğitim yaklaşımına göre yapılandırılan viyolonsel eğitimi dersinin, güzel sanatlar liselerindeki viyolonsel öğrencilerinin bilgi düzeyi ve performansa ilişkin beceriler bakımından akademik başarıları üzerindeki etkisini incelemeyi amaçlamaktadır. Buradan hareketle, dizgeli (programlandırılmış) öğretim modeline dayalı bir viyolonsel eğitimi ders planı geliştirme çalışması yapılmış ve viyolonsel eğitimindeki etkileri denenmiştir.

Tüm bu bilgiler 1şığında, "Güzel sanatlar liselerinde dizgeli öğretim yaklaşımı ile yürütülen viyolonsel eğitimi dersinin öğrenci başarısına etkisi nedir?” sorusuna yanıt aranması bu araştırmanın ana problemini oluşturmaktadır.

Araştırmanın genel amacı doğrultusunda aşağıdaki alt problemlere yanıt aranmıştır:

1. Deney ve kontrol gruplarının bilişsel alan değerlendirme testi toplam öntest-sontest puanları arasinda anlamlı bir fark var midır?

1.1. Deney grubunun bilişsel alan değerlendirme testi öntest puanlanı ile kontrol grubunun öntest puanları arasında anlamlı bir fark var mıdır?

1.2. Kontrol grubunun bilişsel alan değerlendirme testi öntest puanlar1 ile sontest puanları arasinda anlamlı bir fark var midir?

1.3. Deney grubunun bilişsel alan değerlendirme testi öntest puanları ile sontest puanları arasinda anlamlı bir fark var midir?

1.4. Deney grubunun bilişsel alan değerlendirme testi sontest puanları ile kontrol grubunun sontest puanları arasında deney grubunun lehine anlaml bir fark var mıdır?

2. Deney ve kontrol gruplarının performans değerlendirme ölçeği toplam öntest-sontest puanlanı arasinda anlamlı bir fark var midır?

2.1. Deney grubunun performans değerlendirme ölçeği öntest puanları ile kontrol grubu öntest puanları arasında anlamlı bir fark var midır?

2.2. Kontrol grubunun performans değerlendirme ölçeği öntest puanları ile sontest puanları arasinda anlamlı bir fark var midir?

2.3. Deney grubunun performans değerlendirme ölçeği öntest puanları ile sontest puanları arasinda anlamlı bir fark var midir?

2.4. Deney grubunun performans değerlendirme ölçeği sontest puanları ile kontrol grubu sontest puanları arasında deney grubunun lehine anlamlı bir fark var midır?

Türkiye'de, dizgeli eğitim yaklaşımının eğitimin farklı alanlarında denendiği araştırmalara bakıldığında, hedef davranışların kazandırılmasında büyük ölçüde etkili olduğu görülmüştür. Çalg1 eğitimi alanında ise sayısal olarak az olmakla birlikte, hem güzel sanatlar liseleri ele alınarak hem de ülkemizdeki tüm müzik eğitimi kurumları içerisinde viyolonsel çalgısı ele alınarak yapılmış bir çalışmaya rastlanmamıştır.

Bu araştırma, dizgeli öğretim modeli temel alınarak yürütülen viyolonsel öğretimi etkinliklerinin, öğrencilerin müziği bütünsel olarak görmelerini sağlayarak bilişsel alana yönelik bilgi düzeylerinin ve devinişsel alana yönelik performansa ilişkin beceri düzeylerinin geliştirilmesi bakımından önemlidir. 
Şen, Ç., \& Özdemir, M. A. (2017). Viyolonsel eğitimi sürecinde dizgeli öğretim modelinin öğrenci başarısına etkisi. Journal of Human Sciences, 14(4), 3009-3029. doi:10.14687/jhs.v14i4.4881

Dizgeli eğitim yaklaşımının viyolonsel eğitimindeki etkilerinin araştırılmasında ve etkilerinin sistemli şekilde ölçülerek denenen illk çalışma olması da araştırmayı önemli kılmaktadır.

\section{Yöntem}

$\mathrm{Bu}$ araştırma, güzel sanatlar liselerinde yürütülen viyolonsel eğitimi dersinde, dizgeli öğretim modeline uygun yapılandırılan öğrenme-öğretme sürecinin, viyolonsel öğrencilerinin bilişsel ve devinişsel alandaki akademik başarılarına etkisini sınamak amacıyla deneysel modellerden "ÖntestSontest Kontrol Gruplu Deneysel Desen" modeline göre tasarlanmıştır.

Öntest - sontest kontrol gruplu deneysel desen, eğitim ve psikolojide çok sılk kullanılan deneysel desenlerden biridir. Öğrenci başarılarının ve yetenek puanlarının karşılaşıırmasında, ilkokuldan üniversite düzeyine kadar özellikle öğretim uygulamaları ve öğretim programlarının etkilerini değerlendirmek için müzik eğitiminde sık kullanılan bir araştırma modelidir. İlk olarak denek havuzundan biri deney, diğeri kontrol grubu olmak üzere seçkisiz iki grup oluşturulur. Bağımsız değişkenin/değişkenlerin etkililiğini ölçebilmek için, uygulama öncesinde her iki grubun bağımlı değişkenle ilgili ölçümleri alınır. Böylelikle deney grubuna bağımsız değişken uygulanmadan önce öntest ile birinci ölçüm elde edilmiş olur. Deney sürecinde, etkililiği test edilecek işlem deney grubuna uygulanırken kontrol grubuna uygulanmaz. Bağımsız değişken/değişkenler uygulandıktan sonra deney sonunda sontest ile ikinci ölçüm yapılır. Grupların bağımlı değişkene ait ölçümleri aynı araç ya da formlar kullanılarak sontest ile ikinci ölçüm elde edilmiş olur. Deneysel işlemin etkisini görmek amacıyla deney ve kontrol gruplarının bağımlı değişkene ait ölçme sonuçları uygun tekniklerle karşlaştırllır. Deney ve kontrol gruplarında öntest ve sontest arasındaki farklillklar karşılaştırıldığında, deney grubundaki farklılık kontrol grubundakinden yüksek ise bağımsız değişkenin/değişkenlerin bağımlı değişkenlerle ilişkili olduğu sonucuna ulaşıllır. Öntest-sontest kontrol gruplu desen, deneysel işlemin bağımlı değişken üzerindeki etkisini test etmek amaciyla araştırmacıya yüksek oranda istatistiksel güç sağlayan, elde edilen bulguların neden sonuç ilişkisinde yorumlanmasına olanak veren ve davranış bilimlerinde sıklıkla kullanılan güçlü bir desendir (Eakes, 2009: 34; Büyüköztürk, Çakmak, Akgün, Karadeniz ve Demirel, 2008: 196; Frankfort-Nachmias, 1996: akt. Ekiz, 2003: 98; Büyüköztürk, 2001: 27).

Araştırmanın bağımsız değişkenini viyolonsel eğitimi dersi için dizgeli eğitim yaklaşımı ile hazırlanan ders planı, bağımlı değişkenini ise öğrenci başarısı oluşturmaktadır.

Araşturmanın deneysel deseninin simgesel gösterimi Tablo 1.'de verilmiştir.

Tablo 1. Araştırmanın Deneysel Deseni

\begin{tabular}{ccccc}
\hline & Gruplar & Öntest & İşlem & Sontest \\
\hline \multirow{2}{*}{$\mathrm{R}$} & $\mathrm{G}_{1}$ & $\mathrm{~B}_{1}$ & \multirow{2}{*}{ Dizgeli Öğretim } & $\mathrm{B}_{1}$ \\
& $($ Deney $)$ & $\mathrm{P}_{1}$ & & $\mathrm{P}_{1}$ \\
\hline \multirow{2}{*}{$\mathrm{R}$} & $\mathrm{G}_{2}$ & $\mathrm{~B}_{1}$ & \multirow{2}{*}{ Geleneksel Öğretim } & $\mathrm{B}_{1}$ \\
& $($ Kontrol $)$ & $\mathrm{P}_{1}$ & & $\mathrm{P}_{1}$ \\
\hline
\end{tabular}

Tablo 1.'de görülen araştırma desenindeki "R" deneklerin gruplara seçkisiz atandığını, "G1" deney grubunu, "G2" kontrol grubunu, "B1" öntest ve sontest aşamasında uygulanan bilişsel alan değerlendirme testi ile ilgili ölçümleri, "P1" öntest ve sontest aşamasında uygulanan performans değerlendirme ölçeği ile ilgili ölçümleri ifade etmektedir.

\section{1. Çalışma grubu}

Araştırmanın çalışma grubunu, 2009-2010 eğitim öğretim yılı bahar yarıyılında Bursa Zeki Müren Güzel Sanatlar Lisesi Müzik Bölümü’nde öğrenim gören birinci, ikinci ve üçüncü sınıf viyolonsel öğrencileri $(\mathrm{N}=14)$ oluşturmaktadır.

Güzel sanatlar liselerinin müzik bölümleri, her bir sınıf kontenjanı 30 öğrenci olarak belirlenmiş toplam dört sınıftan oluşmaktadır. Lise öğreniminin başındayken, her öğrencinin dört yıl boyunca 
Şen, C.., \& Özdemir, M. A. (2017). Viyolonsel eğitimi sürecinde dizgeli öğretim modelinin öğrenci başarısına etkisi. Journal of Human Sciences, 14(4), 3009-3029. doi:10.14687/jhs.v14i4.4881

eğitimini alacağı çalg1, söz konusu okulların kontenjanları dikkate alınarak belirlenir. Bu genel dağılım içerisinde viyolonsel çalgısını çalmak üzere her yıl için seçilen öğrenci sayısının ortalama 3-5 öğrenci olduğu görülmektedir. Araştırmanın yapıldığı süreçte, adı geçen kurumda dördüncü sınıfta öğrenim gören viyolonsel öğrencisi bulunmamaktadır. Bu nedenle birinci, ikinci ve üçüncü sınıfta öğrenim gören toplam 14 viyolonsel öğrencisinin tümü çalışmaya dâhil edilmiştir.

Araştırmada, viyolonsel eğitimi dersi için dizgeli öğretime dayalı geliştirilen ders planının etkililiğinin sınanmasına yönelik olarak deneklerin giriş davranışları öntest ile ölçülmüştür. Sınıf düzeyine bakılmaksızın öntest sonuçlarına göre eşitlenmiş iki grup oluşturulup seçkisiz olarak deney $(\mathrm{n}=7)$ ve kontrol $(\mathrm{n}=7)$ grupları atanmıştır.

Deney ve kontrol gruplarının oluşturulması aşamasında, yani uygulama öncesinde gruplar arasında eşitliği sağlamak için bilişsel ve devinişsel hedeflere bağlı olarak "bilişsel alan değerlendirme testi" ve "performans değerlendirme ölçeği” kullanılmıştır. Bilişsel ve devinişsel alana yönelik denkliklerinin araştırılması amacıyla her iki gruba da uygulanan öntestlerin sonuçları karşılaştırılmıştır. Grupların bilişsel ve devinişsel alana yönelik durumları ve denklikleri Mann Whitney-U Testi kullanılarak incelenmiştir.

Deney grubuna 8 hafta (16 ders saati) boyunca araştırmacı tarafindan dizgeli öğretim modeline dayalı olarak yapılandırılan "viyolonsel eğitimi ders planı" uygulanmıştır. Kontrol grubuna ise herhangi bir müdahalede bulunulmayarak okuldaki diğer viyolonsel öğretmeni tarafindan geleneksel öğretim uygulanmıştır. Öğretim süreci sonunda yine bilişsel ve devinişsel alana yönelik yapılan sontest ile deney ve kontrol gruplarında oluşan davranış değişiklikleri ölçülmüştür.

\subsection{Veri toplama araçları}

Araştırma verilerinin elde edilmesi amacıyla, bilişsel ve devinişsel alana yönelik olmak üzere araştırmacı tarafindan iki tür ölçek geliştirilmiştir.

Araşturmada, bilişsel alana yönelik "Viyolonsel Dersi Bilişsel Alan Değerlendirme Testi"nin oluşturulması aşamasında, MEB Orta Öğretim Genel Müdürlüğü tarafindan 2009 yllında yayınlanan viyolonsel öğretim programındaki öğrenme alanları ve kazanımları göz önünde bulundurulmuştur. Bilişsel alan değerlendirme testinin, araştırma kapsamında öntest ve sontest aşamalarında kullanılmak üzere belirlenen etüt ve eserlerde yer alan kavram, işaret, teknik ve müziksel bilgileri de içermesine özen gösterilmiştir. Her sınıf düzeyine yönelik toplam 65 maddelik testin oluşturulmasında uzman görüşlerine başvurulmuştur. Oluşturulan test, geçerlik ve güvenirlik hesaplamaları için araştırmanın yapıldığı okulda öğrenim görmekte olan toplam 70 yaylı çalg1 öğrencisine uygulanmış ve Cronbach Alpha istatistik testi ile güvenirliği ölçülmüştür. Başlangıçta 65 soruluk hazırlanan testin madde analizleri sonucu 4 sorusu elenerek 61 sorunun ayırt edici olduğu saptanmışıtır.

Tablo 2. Bilişsel Alan Değerlendirme Testi İç Tutarllık Sonuçları

\begin{tabular}{ccccc}
\hline $\mathrm{n}$ & $\begin{array}{c}\mathrm{n} \\
(\text { madde say1s1) }\end{array}$ & $\bar{x}$ & SS & $\mathrm{r}$ \\
\hline 70 & 61 & 98.90 & 12.22 & 0.915 \\
\hline
\end{tabular}

Tablo 2.'de görüldüğü gibi, bilişsel alan değerlendirme testine ilişkin Cronbach Alpha güvenirlik katsayısının 0.915 olduğu görülmüş ve bu sonuca göre yüksek güvenirlik elde edildiği yargisına varılmıştır. Bu bakımdan, hazırlanan bilişsel alan değerlendirme testinin beklenen yeterlilikleri ölçtüğ̈u ve güvenilir olduğu kararına varılmıştır. Bilişsel alan değerlendirme testi, eğitim öncesinde ve sonrasinda gruplara uygulanmıştır.

Araştırmanın yöntemine ve uygulanacak ders planına dayalı olarak, devinişsel alana yönelik ve performansın ölçülmesine ilişkin "Viyolonsel Dersi Performans Değerlendirme Ölçeği" geliştirilmiştir. Performans değerlendirme ölçeği, MEB Orta Öğretim Genel Müdürlüğü tarafindan 2009 yılında yayınlanan viyolonsel dersin öğretim programındaki öğrenme alanları ve kazanımları göz önünde bulundurularak, yine aynı programın içeriğindeki gözlem formundan, Dalkıran 
Şen, Ç., \& Özdemir, M. A. (2017). Viyolonsel eğitimi sürecinde dizgeli öğretim modelinin öğrenci başarısına etkisi. Journal of Human Sciences, 14(4), 3009-3029. doi:10.14687/jhs.v14i4.4881

(2006)'n keman dersi için geliştirdiği performans ölçeğinden ve Saraç (1996)'in geliştirdiği viyolonsel öğretimi devinişsel alan sinama-ölçme dereceleme ölçeğinden de yararlanılarak, araştırmacının viyolonsel eğitimindeki bireysel deneyimleri ile elde edilmiştir. Performans değerlendirme ölçeğinin oluşturulması aşamasında bir keman, bir viyola ve iki viyolonsel eğitimcisi olmak üzere toplam dört yaylı çalg1 eğitimcisinin uzman görüşüne başvurulmuştur.

Performansın değerlendirilmesi amacıyla öntestte kullanılmak üzere bir etüt ve bir eser, sontestte kullanılmak üzere bir etüt ve bir eser olmak üzere toplam 2 etüt ve 2 eser belirlenmiştir. Öntest ve sontest için belirlenen etüt ve eserler birbirinden farklıdır. Bunun nedeni, deneklerin öntest aşamasında çalıştıklanı etüt ve eserin sontest aşamasında da tekrarlanması halinde doğabilecek hatırlamaların ölçmede yanıltıcı durumlar oluşturabileceği varsayımıdır. Bu durum aynı zamanda tüm deneklerin çalışma sürelerinin eşit tutulmasını da sağlamıştır. Bununla birlikte her iki etüdün ve eserin, performans değerlendirme ölçeğinde yer alan becerilerin ölçülmesi bakımından eşdeğer olduğu, iki viyolonsel eğitimcisinden alınan uzman görüşleri ile desteklenmiştir.

Performansın değerlendirilmesi amaciyla öntest aşamasında Justus Johann Friedrich Dotzauer'in "113 Etudes for Cello" kitabından 21 numaralı etüt, sontest aşamasında ise LouisRaymond Feuillard'ın "Studies of the Young Cellist" kitabından 29 numaralı etüt belirlenmiştir. Öntest aşamasında Johann Sebastian Bach'ın Minuet No:3, sontest aşamasında ise Giovanni Battista Pergolesi’nin Aria eserleri belirlenmiştir. Her iki etüt ve eser, tempo, süre, teknik, konum ve pozisyon geçişleri gibi özellikler bakımından benzerlik taşımaktadır.

Etüt ve eserlerin seçilmesi sürecinde, güzel sanatlar lisesi viyolonsel öğretim programı çerçevesinde yararlanılabilecek düzeydeki, ulaşılabilen viyolonsel literatürü taranmıstır. Belirlenen etüt ve eserlerin seçiminde; denekler tarafindan daha önce icra edilmemiş olmasına, gözlenecek becerilerin ölçülmesinde ayırt edici olmasına ve ders planında belirlenen hedef ve davranışlarla paralellik göstermesine dikkat edilmiştir. Bunun yanı sıra teknik, terim, işaret ve kavramlar gibi müziksel içerik bakımından da ders planları ile uyumlu olmasına özen gösterilmiştir.

Hem öntest hem de sontest aşamasında çalışlacak etüt ve eser tüm deneklere aynı anda verilmiş, böylelikle aynı şartlarda ve eşit sürede çalışmalanı sağlanmıştur. Denekler performans değerlendirme sınavlarına hazırlanırken, herhangi bir öğretmen yardımı ve müdahalesi olmadan bir hafta süreyle kendileri bireysel olarak çalışışlardır.

Performans değerlendirme ölçeği, eğitim öncesi ve sonrasında gruplara uygulanmıştır. Performans değerlendirme ölçeği ile ilgili verilerin toplanması amaciyla, öntestte dört viyolonsel eğitimcisi ve bir keman eğitimcisi olmak üzere toplam beş puanlayıcı, sontestte üç viyolonsel eğitimcisi ve iki keman eğitimcisi olmak üzere yine toplam beş puanlayıc1 değerlendirme yapmıştır. Her bir puanlayıcı, öğrencilerin performansını gözlemleyerek, dinleyerek ve diğer puanlayıcılardan bağımsız olarak performans değerlendirme ölçeğinde yer alan maddelere göre puanlama yapmıştır. Deneklerin öntest ve sontest aşamalarındaki performansları video kamera ile kayıt altına alınmışır.

Gözlemcilerin hem öntestte hem de sontestte öğrencilere verdikleri puanlar tek tek değerlendirilmiş, puanlar arasındaki uyum ve puanlayıcılar arasında fark olup olmadığı Spearman Brown Sıra Farkları Korelasyon Katsayısı ile saptanmıştır.

Tablo 3. Puanlayıcıların Performans Değerlendirme Ölçeği Öntest Puanları Arasındaki İlişki

\begin{tabular}{lccccc}
\hline Puanlayıc1lar & 1. Puanlayıc1 & 2. Puanlayıc1 & 3. Puanlayıc1 & 4. Puanlayıc1 & 5. Puanlayıc1 \\
\hline 1. Puanlayıc1 & 1.000 & & & & \\
2. Puanlayıc1 & $0.927^{* *}$ & 1.000 & & & \\
3. Puanlayıc1 & $0.923^{* *}$ & $0.875^{* *}$ & 1.000 & & \\
4. Puanlayıc1 & $0.937^{* *}$ & $0.909^{* *}$ & $0.831^{* *}$ & 1.000 & \\
5. Puanlayıc1 & $0.967^{* *}$ & $0.953^{* *}$ & $0.894^{* *}$ & $0.928^{* *}$ & 1.000 \\
\hline
\end{tabular}


Şen, Ç., \& Özdemir, M. A. (2017). Viyolonsel eğitimi sürecinde dizgeli öğretim modelinin öğrenci başarısına etkisi. Journal of Human Sciences, 14(4), 3009-3029. doi:10.14687/jhs.v14i4.4881

Tablo 3.'te, deneklere verdikleri puanlar bakımından öntest aşamasında gözlemciler arasındaki istatistiksel uyum görülmektedir.

Tablo 4. Puanlayıcıların Performans Değerlendirme Ölçeği Sontest Puanları Arasındaki İlişki

\begin{tabular}{lccccc}
\hline Puanlayıc1lar & 1. Puanlayıc1 & 2. Puanlayıc1 & 3. Puanlayıc1 & 4. Puanlayıc1 & 5. Puanlayıc1 \\
\hline 1. Puanlayıc1 & 1.000 & & & & \\
2. Puanlayıc1 & $0.977^{* *}$ & 1.000 & & & \\
3. Puanlayıc1 & $0.963^{* *}$ & $0.939^{* *}$ & 1.000 & & \\
4. Puanlayıc1 & $0.883^{* *}$ & $0.886^{* *}$ & $0.869^{* *}$ & 1.000 & \\
5. Puanlayıc1 & $0.977^{* *}$ & $0.964^{* *}$ & $0.939^{* *}$ & $0.912^{* *}$ & 1.000 \\
\hline
\end{tabular}

Tablo 4.'te, deneklere verdikleri puanlar bakımından sontest aşamasında gözlemciler arasındaki istatistiksel uyum görülmektedir.

Araşturmada yer alan beş ayrı gözlemcinin, performans değerlendirme ölçeğinde yer alan maddelere göre hem öntestte hem de sontestte öğrencilere verdikleri puanlar açısından birbirleri arasındaki uyumları araştrılmıştır. Tablo 2. ve Tablo 3.'te görüldügü gibi hem öntestte hem de sontestte tüm puanlayıcılar arasında pozitif yönlü, yüksek ve anlamlı ilişkiler bulunmuştur. $\mathrm{Bu}$ nedenle, gözlemcilerin deneklere verdikleri puanların uyumlu olduğu ve gözlemciler arasında istatistiksel olarak anlamlı bir fark olmadığı söylenebilir $(\mathrm{p}<0.01)$.

\subsection{Verilerin toplanmas1}

Araştırmanın yöntemine dayalı olarak viyolonsel öğrencilerinin bilgi düzeyi ve performansla ilgili becerileri içeren akademik başarılarını geliştirmek amacıyla, dizgeli öğretim modeline göre yapılandırılan ve 8 haftalık süreçte toplam 16 ders saatini kapsayan ders planı hazırlanmıştır. Ders planı hazırlanırken öncelikle sekiz haftalık konu seçimi yapılmış, ilgili konular paralelinde hedef ve davranışlar belirlenerek derslerin içeriği dizgeli eğitim yaklaşımına uygun düzenlenmiştir. Öğrencilerin bilişsel ve devinişsel alandaki akademik başarı düzeyleri ölçüleceğinden, hedef ve davranışlar da bu doğrultuda belirlenmiştir.

Deney ve kontrol grupları belirlendikten sonra araştırmacı tarafindan deney grubundaki her öğrenci ile haftada iki ders saati olmak üzere, sekiz hafta süreyle ve toplam on altı ders saati boyunca, oluşturulan ders planı doğrultusunda bire bir eğitim sürdürülmüştür.

Deney grubu öğrencileri ile yürütülen derslerde işlenen konular dizgeli eğitimin basamaklarına göre düzenlenmiş olup öğrenci merkezli eğitimin gereği olarak öğrenci kattlımı üst düzeyde tutulmaya çalışılmıştır. Ünitelerde yer alan konular her öğrenciyle ayrıntılı olarak çalışılmıştır. Özellikle rahat bir duruş ve tutuş sağlanması için viyolonsel çalarken vücudun iş gören bölümlerinin kullanımı, detayları ile gösterilerek açıklanmaya çalışılmıştır. Sağ ve sol elin alması gereken durumlar ve yaptıkları hareketler, çalışlan gamlar üzerinde açıklanarak gösterilmiştir. Sözü edilen becerileri öğrencilerin hedeflenen düzeyde kazanmalarını sağlamak için McCord (1976: akt. Romiszowski, 1984: 228) ve Fidan (1996: 202)'ın beceri öğretimi ile ilgili belirttiği aşamaların ve basamakların izlenmesine özen gösterilmiştir. Öğrencilerin, becerileri kendi kendine doğru şekilde yapmaları sağlanana kadar gerekli dönüt ve düzeltmeler sürdürülmüş, pekiştireçlerin yerinde ve zamanında kullanılmasına dikkat edilmiştir. Böylelikle öğrencilerin motivasyonu canlı tutulmaya çalışılmıştır.

Sontest aşamasındaki performans değerlendirme sınavında seslendirmesi yapilacak etüt ve esere hazırlık oluşturması amacıyla, derslerde buna yönelik egzersiz, etüt ve eserler çalışılmıştır. Öte yandan yine sontest aşamasında uygulanacak bilişsel alan değerlendirme testinde yer alan sorulara yönelik bilişsel alana özgü çalışmalar yapılmıştır. Bunun için derslerde çalışılan egzersiz, etüt ve eserler üzerinde yer alan teknik, terim, işaret ve kavramlar gibi müziksel içerikler hakkında gerekli bilgilendirmeler yapılmıştır. Aynı zamanda bilişsel alanı desteklemek amacıyla ünitelere ilişkin hazırlanan sunum kâğıtları öğrencilere verilmiştir. 
Şen, C.., \& Özdemir, M. A. (2017). Viyolonsel eğitimi sürecinde dizgeli öğretim modelinin öğrenci başarısına etkisi. Journal of Human Sciences, 14(4), 3009-3029. doi:10.14687/jhs.v14i4.4881

Deney grubuna dizgeli eğitim modeline dayalı öğretim yapılırken kontrol grubuna herhangi bir müdahalede bulunulmamış, kontrol grubundaki öğrenciler aynı süreçte aynı ders saati kadar geleneksel yöntemlerle eğitimlerine devam etmiştir. Kendilerine uygulanan öğretim hakkında kontrol grubunda yer alan diğer öğrencilerle herhangi bir etkileşimde bulunmamalarının önemi deney grubu öğrencilerine özellikle vurgulanmıştır.

Oluşturulan ders planı doğrultusunda, devinişsel alanla ilgili hedef davranışların kazandırılmasına yönelik, yararlanılabilecek düzeydeki ulaşılabilen viyolonsel literatürü taranarak derslerde kullanılacak alıştırma, etüt ve eserler belirlenmiştir. Derslerde çalışılmak üzere seçilen etüt ve eserlerin, sontest aşamasındaki performans değerlendirmesi amacıyla belirlenen etüt ve eserden farklı olmasına özellikle dikkat edilmiştir. Çünkü öğrencilerin sontest aşamasında seslendirilecek etüt ve eser ile ilgili çalışmalarını, öğretmen rehberliği olmadan kendilerinin planlaması beklenmiştir. Böylelikle, dizgeli eğitimin ilkeleri doğrultusunda her öğrencinin bilgiyi bulup çıarma, anlamlandırma, kullanma ve yeniden yapılandırma imkânı doğmuştur. Bu doğrultuda, sontest için belirlenen etüt ve eser, performans sinavından bir hafta önce tüm deneklere aynı anda verilerek, sontestte puanlanacak performansların deney ve kontrol grupları için eşit şartlarda başlaması sağlanmıştır. Sontest için verilen etüt ve eseri kendileri bireysel olarak çalışan öğrencilere bu süreçte hiçbir şekilde ipucu verilmemiş, herhangi bir hatırlatmada bulunulmamıştır.

\subsection{Verilerin çözümlenmesi}

Araştırmada veriler, deney ve kontrol gruplarına göre ayrı olmak üzere bilişsel alan değerlendirme testi verileri ve performans değerlendirme ölçeği verileri şeklinde sınıflandırılmıştır. Ölçeklerden elde edilen veriler, deney ve kontrol grupları açısından ayrı ayrı değerlendirilerek istatistiksel analizler uygulanmıştır.

Deney ve kontrol gruplarının deney öncesi denkliklerini belirlemek amacı ile öntestler üzerinde Mann Whitney-U testi uygulanmıştır. Her iki grubun deney sonrası ulaştıklanı seviyelerini, yani deney ve kontrol gruplarının sontest puanları arasındaki farkı belirlemek amacı ile yine Mann Whitney-U testi kullanılmıştır. Sontest puanları üzerinde Mann Whitney-U testi uygulanarak deney sonunda hangi grubun daha fazla ilerleme kaydetmiş olduğu belirlenmiştir.

Araştırmada deney ve kontrol gruplarının kendi içlerinde bilişsel alan değerlendirme testinden ve performans değerlendirme ölçeğinden aldıkları öntest ve sontest puanları için Wilcoxon işaretli sıralar testi kullanılmıştır. Bu testin kullanılmasındaki amaç, uygulanan öğretim sonucunda deney ve kontrol gruplarının nasıl bir gelişme gösterdiğini belirlemektir. Böylece deney ve kontrol gruplarının bilişsel alan değerlendirme testi ve performans testi açısından gelişim dereceleri kendi içlerinde karşılaştırılmış ve daha fazla gelişme kaydeden grup belirlenmiştir (Otacıoğlu, 2005: 96).

\section{Bulgular}

Alt problem 1. ile ilgili bulgular ve yorum

Deney ve kontrol gruplarının bilişsel alan değerlendirme testi toplam öntest-sontest puanları arasinda anlamlı bir fark var midir?

Tablo 5. Grupların Bilişsel Alan Değerlendirme Testi Toplam Öntest-Sontest Puanlarının Tanımlayıcı Değerleri

\begin{tabular}{ccccc}
\hline $\begin{array}{c}\text { Bilişsel Alan } \\
\text { Değerlendirme Testi }\end{array}$ & Grup & $\mathrm{n}$ & $\bar{x}$ & ss \\
\hline \multirow{2}{*}{ Öntest } & Deney & 7 & 46.00 & 5.88 \\
\cline { 2 - 5 } & Kontrol & 7 & 46.85 & 8.82 \\
\hline \multirow{2}{*}{ Sontest } & Deney & 7 & 60.43 & 5.38 \\
\cline { 2 - 5 } & Kontrol & 7 & 46.85 & 6.22 \\
\hline
\end{tabular}


Şen, C.., \& Özdemir, M. A. (2017). Viyolonsel eğitimi sürecinde dizgeli öğretim modelinin öğrenci başarısına etkisi. Journal of Human Sciences, 14(4), 3009-3029. doi:10.14687/jhs.v14i4.4881

Tablo 5.'te deney ve kontrol gruplarının hem öntest hem de sontest aşamasındaki bilişsel alan değerlendirme testine ilişkin toplam puanlarının ortalamaları ve standart sapmaları görülmektedir. Buna göre bilişsel alan değerlendirme testi toplam puanları içinde en düşük ortalama $(\bar{x}=46.00)$ deney grubunun öntest puanlarında, en yüksek ortalama ise $(\bar{x}=60.43)$ deney grubunun sontest puanlarında elde edilmiştir. Grupların bilişsel alan değerlendirme testi öntest ortalamalarına bakıldığında birbirlerine denk olduğu, sontest ortalamalarına bakıldığında ise deney grubunun lehine anlamlı fark olduğu görülmektedir.

Alt problem 1.1. ile ilgili bulgular ve yorum

Deney grubunun bilişsel alan değerlendirme testi öntest puanları ile kontrol grubunun öntest puanları arasinda anlamlı bir fark var midır?

Tablo 6. Grupların Bilişsel Alan Değerlendirme Testi Toplam Öntest Puanlarına Göre Mann Whitney-U Testi Sonuçları

\begin{tabular}{ccccccc}
\hline Grup & $\mathrm{N}$ & $\begin{array}{c}\text { Siralamalar } \\
\text { Ortalamas }\end{array}$ & $\begin{array}{c}\text { Siralamalar } \\
\text { Toplam }\end{array}$ & $\mathrm{U}$ & $\mathrm{z}$ & $\mathrm{p}$ \\
\hline Deney & 7 & 7.50 & 52.50 & 24.50 & .000 & $1.000^{*}$ \\
\hline Kontrol & 7 & 7.50 & 52.50 & & & \\
\hline
\end{tabular}

Grupların bilişsel alan değerlendirme testi toplam öntest puanları arasındaki farkın belirlenmesine yönelik Mann Whitney-U testi yapılmış ve Tablo 6.'da görüldügü gibi gruplar arasında anlamlı bir fark bulunmamıştır ( $\mathrm{p}>.05)$. Bu sonuç, deney ve kontrol gruplarının bilişsel alan değerlendirme testi toplam öntest puanları açısından denk olduğunu göstermektedir.

Alt problem 1.2. ile ilgili bulgular ve yorum

Kontrol grubunun bilişsel alan değerlendirme testi öntest puanları ile sontest puanları arasında anlamlı bir fark var midır?

Tablo 7. Kontrol Grubunun Bilişsel Alan Değerlendirme Testi Toplam Öntest-Sontest Puanlarının Wilcoxon İşaretli Sıralar Testi Sonuçları

\begin{tabular}{|c|c|c|c|c|c|}
\hline $\begin{array}{l}\text { Kontrol Grubu } \\
\text { Öntest-Sontest }\end{array}$ & $\mathrm{n}$ & $\begin{array}{l}\text { Siralamalar } \\
\text { Ortalamas1 }\end{array}$ & Siralamalar Toplam & $\mathrm{z}$ & $\mathrm{p}$ \\
\hline Negatif Sira & 2 & 4.75 & 9.50 & \multirow{3}{*}{-.210} & \multirow{3}{*}{$.833^{*}$} \\
\hline Pozitif Sıra & 4 & 2.88 & 11.50 & & \\
\hline Eşit & 1 & - & - & & \\
\hline
\end{tabular}

Kontrol grubunun bilişsel alan değerlendirme testi toplam öntest-sontest puanları arasındaki farkın belirlenmesine yönelik Wilcoxon testi yapılmıș ve Tablo 7.'de görüldüğü gibi anlamlı bir fark bulunmamıştır ( $\mathrm{p}>.05)$. Bu sonuç, geleneksel öğretim yapılan kontrol grubundaki öğrencilerin eğitim öncesi ve sonrası bilgi düzeylerinde anlamlı bir artışı olmadığını göstermektedir.

Alt problem 1.3. ile ilgili bulgular ve yorum

Deney grubunun bilişsel alan değerlendirme testi öntest puanları ile sontest puanları arasında anlamlı bir fark var midır?

Tablo 8. Deney Grubunun Bilişsel Alan Değerlendirme Testi Toplam Öntest-Sontest Puanlarının Wilcoxon İşaretli Sıralar Testi Sonuçları

\begin{tabular}{|c|c|c|c|c|c|}
\hline $\begin{array}{c}\text { Deney Grubu } \\
\text { Öntest-Sontest }\end{array}$ & $\mathrm{n}$ & $\begin{array}{l}\text { Siralamalar } \\
\text { Ortalamas1 }\end{array}$ & $\begin{array}{c}\text { Siralamalar } \\
\text { Toplamı }\end{array}$ & z & $\mathrm{p}$ \\
\hline Negatif Sira & 0 & .00 & .00 & \multirow{3}{*}{-2.371} & \multirow{3}{*}{$.018^{*}$} \\
\hline Pozitif Sıra & 7 & 4.00 & 28.00 & & \\
\hline Eşit & 0 & - & - & & \\
\hline
\end{tabular}


Şen, Ç., \& Özdemir, M. A. (2017). Viyolonsel eğitimi sürecinde dizgeli öğretim modelinin öğrenci başarısına etkisi. Journal of Human Sciences, 14(4), 3009-3029. doi:10.14687/jhs.v14i4.4881

Deney grubunun bilişsel alan değerlendirme testi toplam öntest-sontest puanları arasındaki farkın belirlenmesine yönelik Wilcoxon testi yapılmış ve Tablo 8.'de görüldüğü gibi anlamlı bir fark bulunmuştur $(\mathrm{p}<.05)$. Bu sonuç, dizgeli öğretim modeline göre hazırlanan ders planının, deney grubundaki öğrencilerin bilgi düzeylerini olumlu yönde geliştirdiğini göstermektedir.

Alt problem 1.4. ile ilgili bulgular ve yorum

Deney grubunun bilişsel alan değerlendirme testi sontest puanları ile kontrol grubunun sontest puanları arasında deney grubunun lehine anlamlı bir fark var midır?

Tablo 9. Grupların Bilişsel Alan Değerlendirme Testi Toplam Sontest Puanlarına Göre Mann Whitney-U Testi Sonuçları

\begin{tabular}{|c|c|c|c|c|c|c|}
\hline Grup & $\mathrm{N}$ & $\begin{array}{l}\text { Siralamalar } \\
\text { Ortalamasi }\end{array}$ & $\begin{array}{l}\text { Siralamalar } \\
\text { Toplamı }\end{array}$ & $\mathrm{U}$ & $z$ & $\mathrm{p}$ \\
\hline Deney & 7 & 10.71 & 75.00 & \multirow{2}{*}{2.00} & \multirow{2}{*}{-2.891} & \multirow{2}{*}{$.004 *$} \\
\hline Kontrol & 7 & 4.29 & 30.00 & & & \\
\hline
\end{tabular}

Grupların bilişsel alan değerlendirme testi toplam sontest puanları arasındaki farkın belirlenmesine yönelik Mann Whitney-U testi yapılmış ve Tablo 9.'da görüldügü gibi gruplar arasında anlamlı bir fark bulunmuştur $(\mathrm{p}<.05)$. Bu sonuç, sıra ortalamaları dikkate alındığında, dizgeli öğretim modeline göre hazırlanan ders planının uygulanmasıyla ilgili bir deneysel çalışma sonucunda, ders planının uygulandığı deney grubu ile geleneksel öğretim yapılan kontrol grubunun bilişsel alan değerlendirme testi puanları arasında deney grubunun lehine anlamlı bir fark olduğunu göstermektedir.

Alt problem 2. ile ilgili bulgular ve yorum

Deney ve kontrol gruplanının performans değerlendirme ölçeği toplam öntest-sontest puanlanı arasinda anlamlı bir fark var midir?

Tablo 10. Grupların Performans Değerlendirme Ölçeği Toplam Puanlarının Tanımlayıcı Değerleri

\begin{tabular}{ccccc}
\hline $\begin{array}{c}\text { Performans } \\
\text { Değerlendirme Testi }\end{array}$ & Grup & $\mathrm{n}$ & $\bar{x}$ & SS \\
\hline \multirow{2}{*}{ Öntest } & Deney & 7 & 48.80 & 10.65 \\
\cline { 2 - 5 } & Kontrol & 7 & 49.17 & 8.16 \\
\hline \multirow{2}{*}{ Sontest } & Deney & 7 & 57.94 & 13.14 \\
\cline { 2 - 5 } & Kontrol & 7 & 42.57 & 9.98 \\
\hline
\end{tabular}

Tablo 10.'da deney ve kontrol gruplarının hem öntest hem de sontest aşamasındaki performans değerlendirme ölçeğine ilisskin toplam puanlarının ortalamaları ve standart sapmaları görülmektedir. Buna göre performans değerlendirme ölçeği toplam puanları içinde en düşük ortalama $(\bar{x}=42.57)$ kontrol grubu sontest puanlarında, en yüksek ortalama ise $(\bar{x}=57.94)$ deney grubu sontest puanlarında elde edilmiştir. Grupların performans değerlendirme ölçeği öntest ortalamalarına bakıldığında birbirlerine denk olduğu, sontest ortalamalarına bakıldığında ise deney grubunun lehine anlamlı fark olduğu görülmektedir.

Alt problem 2.1. ile ilgili bulgular ve yorum

Deney grubunun performans değerlendirme ölçeği öntest puanları ile kontrol grubu öntest puanları arasında anlamlı bir fark var midır? 
Şen, Ç., \& Özdemir, M. A. (2017). Viyolonsel eğitimi sürecinde dizgeli öğretim modelinin öğrenci başarısına etkisi. Journal of Human Sciences, 14(4), 3009-3029. doi:10.14687/jhs.v14i4.4881

Tablo 11. Grupların Performans Değerlendirme Ölçeği Toplam Öntest Puanlarına Göre Mann Whitney-U Testi Sonuçları

\begin{tabular}{|c|c|c|c|c|c|c|}
\hline Grup & $\mathrm{N}$ & $\begin{array}{l}\text { Siralamalar } \\
\text { Ortalamas1 }\end{array}$ & $\begin{array}{c}\text { Siralamalar } \\
\text { Toplamı } \\
\end{array}$ & $\mathrm{U}$ & $\mathrm{z}$ & $\mathrm{p}$ \\
\hline Deney & 7 & 7.57 & 53.00 & \multirow{2}{*}{24.00} & \multirow{2}{*}{-.064} & \multirow{2}{*}{$.949 *$} \\
\hline Kontrol & 7 & 7.43 & 52.00 & & & \\
\hline
\end{tabular}

Grupların performans değerlendirme ölçeği toplam öntest puanları arasındaki farkın belirlenmesine yönelik Mann Whitney-U testi yapılmış ve Tablo 11.'de görüldüğü gibi gruplar arasında anlamlı bir fark bulunmamıştır ( $\mathrm{p}>.05)$. Bu sonuç, deney ve kontrol gruplarının performans değerlendirme ölçeği toplam öntest puanları açısından denk olduğunu göstermektedir.

Alt problem 2.2. ile ilgili bulgular ve yorum

Kontrol grubunun performans değerlendirme ölçeği öntest puanlar1 ile sontest puanları arasinda anlamlı bir fark var midir?

Tablo 12. Kontrol Grubunun Performans Değerlendirme Ölçeği Toplam Öntest-Sontest Puanlarının Wilcoxon İşaretli Sıralar Testi Sonuçları

\begin{tabular}{cccccc}
\hline $\begin{array}{c}\text { Kontrol Grubu } \\
\text { Öntest-Sontest }\end{array}$ & $\mathrm{n}$ & $\begin{array}{c}\text { Siralamalar } \\
\text { Ortalamas }\end{array}$ & $\begin{array}{c}\text { Stralamalar } \\
\text { Toplamı }\end{array}$ & $\mathrm{z}$ & $\mathrm{p}$ \\
\cline { 1 - 4 } Negatif Sıra & 5 & 4.80 & 24.00 & & \\
\cline { 1 - 4 } Pozitif Sıra & 2 & 2.00 & 4.00 & & $.091 *$ \\
\hline Eşit & 0 & - & - & \\
\hline
\end{tabular}

Kontrol grubunun performans değerlendirme ölçeği toplam öntest-sontest puanları arasındaki farkın belirlenmesine yönelik Wilcoxon testi yapılmış ve Tablo 12.'de görüldüğü gibi anlamlı bir fark bulunmamıştır ( $\mathrm{p}>.05)$. Bu sonuç, geleneksel öğretim yapılan kontrol grubundaki öğrencilerin eğitim öncesi ve sonrası performans başarılarında anlamlı bir gelişmenin olmadığını göstermektedir.

Alt problem 2.3. ile ilgili bulgular ve yorum

Deney grubunun performans değerlendirme ölçeği öntest puanları ile sontest puanları arasında anlamlı bir fark var midır?

Tablo 13. Deney Grubunun Performans Değerlendirme Ölçeği Toplam Öntest-Sontest Puanlarının Wilcoxon İşaretli Sıralar Testi Sonuçları

\begin{tabular}{|c|c|c|c|c|c|}
\hline $\begin{array}{c}\text { Deney Grubu } \\
\text { Öntest-Sontest }\end{array}$ & $\mathrm{n}$ & $\begin{array}{l}\text { Siralamalar } \\
\text { Ortalamas1 }\end{array}$ & $\begin{array}{c}\text { Siralamalar } \\
\text { Toplam1 }\end{array}$ & Z & $\mathrm{p}$ \\
\hline Negatif Sıra & 0 & .00 & .00 & \multirow{3}{*}{-2.366} & \multirow{3}{*}{$.018^{*}$} \\
\hline Pozitif Sıra & 7 & 4.00 & 28.00 & & \\
\hline Eşit & 0 & - & - & & \\
\hline
\end{tabular}

Deney grubunun performans değerlendirme ölçeği toplam öntest-sontest puanları arasındaki farkın belirlenmesine yönelik Wilcoxon testi yapılmış ve Tablo 13.'te görüldüğü gibi anlamlı bir fark bulunmuştur $(\mathrm{p}<.05)$. Bu sonuç, dizgeli öğretim modeline göre hazırlanan ders planının, deney grubundaki öğrencilerin performans başarısını olumlu yönde geliştirdiğini göstermektedir.

Alt problem 2.4. ile ilgili bulgular ve yorum

Deney grubunun performans değerlendirme ölçeği sontest puanları ile kontrol grubu sontest puanları arasında deney grubunun lehine anlamlı bir fark var mıdır? 
Şen, Ç., \& Özdemir, M. A. (2017). Viyolonsel eğitimi sürecinde dizgeli öğretim modelinin öğrenci başarısına etkisi. Journal of Human Sciences, 14(4), 3009-3029. doi:10.14687/jhs.v14i4.4881

Tablo 14. Grupların Performans Değerlendirme Ölçeği Toplam Sontest Puanlarına Göre Mann Whitney-U Testi Sonuçları

\begin{tabular}{|c|c|c|c|c|c|c|}
\hline Grup & $\mathrm{N}$ & $\begin{array}{l}\text { Siralamalar } \\
\text { Ortalamas }\end{array}$ & $\begin{array}{l}\text { Siralamalar } \\
\text { Toplamı }\end{array}$ & $\mathrm{U}$ & $\mathrm{z}$ & $\mathrm{p}$ \\
\hline Deney & 7 & 9.79 & 68.50 & \multirow{2}{*}{8.50} & \multirow{2}{*}{-2.047} & \multirow{2}{*}{$.041 *$} \\
\hline Kontrol & 7 & 5.21 & 36.50 & & & \\
\hline
\end{tabular}

Grupların performans değerlendirme ölçeği toplam sontest puanları arasındaki farkın belirlenmesine yönelik Mann Whitney-U testi yapılmış ve Tablo 14.'te görüldüğü gibi gruplar arasında anlamlı bir fark bulunmuştur $(\mathrm{p}<.05)$. Bu sonuç, sıra ortalamaları dikkate alındığında, dizgeli öğretim modeline göre hazırlanan ders planının uygulanması ile ilgili bir deneysel çalışma sonucunda, ders planının uygulandığı deney grubu ile geleneksel öğretim yapılan kontrol grubunun performans değerlendirme ölçeği toplam puanları arasında deney grubunun lehine anlamlı bir fark olduğunu göstermektedir.

\section{Sonuç}

Araştırmanın verileri doğrultusunda elde edilen bulgularla ilgili sonuçlar aşağıda açıklanmıştır:

1. Dizgeli öğretim modeline göre yapılandırılan viyolonsel ders planının uygulandığı deney grubu ile geleneksel öğretim yapılan kontrol grubu arasında, deney öncesindeki bilişsel alan değerlendirme testi toplam öntest puanları bakımından anlamlı bir fark bulunmamıştır. Bu sonuç, uygulama öncesinde deney ve kontrol gruplarının, viyolonsel eğitimi dersine yönelik bilişsel alanla ilgili ön öğrenmeleri bakımından birbirine denk olduğunu göstermektedir.

2. Geleneksel öğretim yapılan kontrol grubunun deney öncesindeki bilişsel alan değerlendirme testi toplam öntest puanları ile deney sonrasındaki toplam sontest puanları arasında anlamlı bir fark bulunmamıştır. Bu sonuç, kontrol grubunda geleneksel öğretim yoluyla yürütülen viyolonsel eğitimi derslerinin, kontrol grubundaki öğrencilerin bilişsel alana yönelik öğrenme düzeylerinin arttırılmasında yeterli ölçüde etkili olamadığını göstermektedir.

3. Dizgeli öğretim modeline göre yapılandırılan viyolonsel ders planının uygulandığı deney grubunun, uygulama öncesindeki bilişsel alan değerlendirme testi toplam öntest puanlan ile uygulama sonrasındaki toplam sontest puanları arasında anlamlı düzeyde fark bulunmuştur. $\mathrm{Bu}$ sonuç, dizgeli öğretim modeline göre yürütülen viyolonsel eğitimi derslerinin, deney grubundaki öğrencilerin bilişsel alana yönelik öğrenmelerinde önemli ölçüde etkili olduğunu ve bu yöndeki kazanımlarını arttırdığını göstermektedir.

4. Dizgeli öğretim modeline göre yapılandırılan viyolonsel ders planının uygulandığı deney grubu ile geleneksel öğretim yapılan kontrol grubu arasında, deney sonrasındaki bilişsel alan değerlendirme testi toplam sontest puanları bakımından deney grubunun lehine anlamlı bir fark bulunmuştur. $\mathrm{Bu}$ sonuç, dizgeli öğretim modeline göre yapılandırılan viyolonsel dersinin yürütüldüğ̈̈ deney grubundaki öğrencilerin, geleneksel öğretim yoluyla viyolonsel eğitimi alan kontrol grubundaki öğrencilere göre daha fazla bilişsel öğrenme elde ettiğini; dolayısıyla dizgeli eğitim yaklaşımı ile yapılan öğretimin, viyolonsel eğitiminde öğrencilerin bilişsel alana yönelik öğrenmeleri üzerinde daha etkili olduğunu göstermektedir.

5. Dizgeli öğretim modeline göre yapılandırılan viyolonsel ders planının uygulandı̆̆ı deney grubu ile geleneksel öğretim yapılan kontrol grubu arasında, deney öncesindeki performans değerlendirme ölçeği toplam öntest puanları bakımından anlamlı bir fark bulunmamıştır. Bu sonuç, uygulama öncesinde deney ve kontrol gruplarının, viyolonsel eğitimi dersine yönelik devinişsel beceriler bakımından birbirine denk olduğunu göstermektedir.

6. Geleneksel öğretim yapılan kontrol grubunun deney öncesindeki performans değerlendirme ölçeği toplam öntest puanları ile deney sonrasındaki toplam sontest puanları arasında anlamlı bir fark bulunmamıştır. Bu sonuç, kontrol grubunda geleneksel öğretim yoluyla yürütülen viyolonsel 
Şen, Ç., \& Özdemir, M. A. (2017). Viyolonsel eğitimi sürecinde dizgeli öğretim modelinin öğrenci başarısına etkisi. Journal of Human Sciences, 14(4), 3009-3029. doi:10.14687/jhs.v14i4.4881

eğitimi derslerinin, kontrol grubundaki öğrencilerin devinişsel alana yönelik beceri düzeylerinin arttırılmasında yeterli ölçüde etkili olamadığını göstermektedir.

7. Dizgeli öğretim modeline göre yapılandırılan viyolonsel ders planının uygulandığı deney grubunun, uygulama öncesindeki performans değerlendirme ölçeği toplam öntest puanları ile uygulama sonrasındaki toplam sontest puanları arasında anlamlı düzeyde fark bulunmuştur. $\mathrm{Bu}$ sonuç, dizgeli öğretim modeline göre yürütülen viyolonsel eğitimi derslerinin, deney grubundaki öğrencilerin devinişsel alana yönelik becerileri üzerinde önemli ölçüde etkili olduğunu ve bu yöndeki kazanımlarını arttırdığını göstermektedir.

8. Dizgeli öğretim modeline göre yapılandırılan viyolonsel ders planının uygulandığı deney grubu ile geleneksel ögrretim yapılan kontrol grubu arasında, deney sonrasındaki performans değerlendirme ölçeği toplam sontest puanları bakımından deney grubunun lehine anlamlı bir fark bulunmuştur. $\mathrm{Bu}$ sonuç, dizgeli öğretim modeline göre yapılandırılan viyolonsel dersinin yürütüldüğü deney grubundaki öğrencilerin, geleneksel öğretim yoluyla viyolonsel eğitimi alan kontrol grubundaki öğrencilere göre daha fazla devinişsel beceri elde ettiğini; dolayısıyla dizgeli eğitim yaklaşımı ile yapılan öğretimin, öğrencilerin viyolonsel çalmaya yönelik devinişsel becerilerini arttırmada daha etkili olduğunu göstermektedir.

\subsection{Tartı̧̧ma}

Eğitim sürecinin başarısı, öğretim sürecinin nitelikli şekilde planlanması ile büyük ölçüde ilişkilidir. Dizgeli öğretimin bu noktada getirdiği önemli kazanç, öğretim sürecinin basamaklarındaki her türlü detayı ortaya koyarak belirlemesidir.

$\mathrm{Bu}$ araştırmada, dizgeli öğretim modelinin güzel sanatlar liselerinde yürütülen viyolonsel eğitimi dersi kapsamında, öğrencilerin bilişsel ve devinişsel alana yönelik akademik başarıları üzerindeki etkisi incelenmiştir. Buna göre, araştırmacı tarafından dizgeli öğretim yaklaşımı doğrultusunda yapılandırılan viyolonsel eğitimi derslerinin, öğrencilerin bilgi ve performans düzeylerini attırmada etkili olduğu görülmüştür.

Otacıoğlu (2005), müzik öğretmeni adaylarının piyano eğitiminde dizgeli öğretime dayalı bir model denemesi gerçekleştirmiş ve deney süreci sonunda, geliştirilen piyano dersi öğretim modelinin, klasik öğretime dayalı piyano eğitimine göre daha etkili olduğu saptanmıştır.

Piji (2006), müzik öğretmeni adayları için dizgeli öğretime dayalı eşlik dersi program geliştirme çalışması yapmıştır. Araştırmadan elde edilen sonuçlar, dizgeli öğretime göre geliştirilen eşlik dersi programının başarı, gözlem, tutum ve kalıcılık puanları üzerinde anlamlı düzeyde etkili olduğunu göstermiştir.

Yokuş (2009a), müzik öğretmenliği piyano eğitimi dersinde, öğrenme stratejilerinin geliştirilmesine yönelik etkinlikleri içeren, dizgeli öğretim modeline dayalı öğretim programı hazırlamıs ve deney grubuna uygulamıştır. Uygulama süreci sonunda deney grubundaki öğrencilerin bilgi düzeylerinde, performans başarılarında ve üstbilişsel farkındalık düzeylerinde anlamlı bir artış görülmüsstür. Öte yandan bu artışın kontrol grubuna göre daha fazla olduğu belirlenmiştir.

Yokuş (2009b), müzik öğretmenliği gitar eğitimi dersinde, üstbilişsel becerilerin geliştirilmesine yönelik etkinlikleri içeren, dizgeli öğretime dayalı öğretim programı hazırlamış ve deney grubuna uygulamıştır. Araştırma sonunda, deney grubundaki öğrencilerin üstbilişsel farkındalık düzeyleri, gitar performans başarıları ve gitar dersi bilgi düzeylerinde anlamlı bir artış görülmüştür. Öte yandan bu artışın kontrol grubuna göre daha fazla olduğu belirlenmiştir.

Eldemir (2010) çalışmasında, müzik öğretmenliği Geleneksel Türk Sanat Müziği dersinde uygulanan dizgeli öğretim yönteminin öğrenci erişisi üzerindeki etkisini ortaya koymay1 amaçlamıştur. Araştırma sonunda, dizgeli öğretim yönteminin Geleneksel Türk Sanat Müziği eğitimini nitelik ve verimlilik bakımından bulunduğu noktadan daha üst noktaya taşıyabilecek özellikte bir yaklaşım olduğu sonucuna varılmıştır.

Küpana (2011) çalışmasında, dizgeli eğitime dayalı olarak geliştirilen piyanoda deşifre öğretimi programının, müzik öğretmeni adaylarının piyanoda deşifreye yönelik bilgi düzeylerine, deşifre 
Şen, Ç., \& Özdemir, M. A. (2017). Viyolonsel eğitimi sürecinde dizgeli öğretim modelinin öğrenci başarısına etkisi. Journal of Human Sciences, 14(4), 3009-3029. doi:10.14687/jhs.v14i4.4881

becerilerine, müzikal algilama düzeylerine ve piyano dersine yönelik tutumlarına etkisinin, klasik eğitime göre daha etkili ve geliştirici olduğu sonucuna varmıstır.

Akgül (2013) çalışmasında, enstrüman eşlikli uygulamaların ilköğretim 6. sınıf öğrencilerinin müzik dersine yönelik başarı ve tutumlarına etkisini incelemiştir. Dizgeli eğitim sistematĭgi ile hazırlanmış eşlikli müzik dersi etkinliklerinin yürütüldügü deney grubu ile geleneksel eğitimin yürütüldüğ̈̈ kontrol grubu arasında, başarı testinden ve tutum ölçeğinden aldıkları puanlar bakımından deney grubunun lehine anlamlı düzeyde fark bulunmuştur.

Özdemir (2014) araştırmasının sonucunda, dizgeli öğretime göre hazırlanan gitar dersi öğretim programının, müzik öğretmeni adaylarının bilgi düzeylerinde, performans düzeylerinde, gitar çalışma zihinsel alg1 ve tutum düzeylerinde, geleneksel eğitime göre daha etkili ve geliştirici olduğunu saptamıştur.

Eğitimin farklı alanlarında yapılan araştırmalara bakıldı̆̆ında dizgeli öğretim uygulamalarının geleneksel öğretim uygulamalarına kıyasla daha etkili olduğu görülmektedir. Müzik eğitimi alanında yapılmış ilgili araştırmalardan da benzer sonuçlar elde edilmiştir. Özellikle bilişsel ve devinişsel alanda başarının artması ile ilgili bulgular, bu araştırma çerçevesinde viyolonsel eğitimine yönelik dizgeli öğretim uygulamalarından elde edilen sonuçları destekler niteliktedir. Sonuçların paralellik göstermesi nedeniyle dizgeli öğretimin, eğitimin farklı alanlarında geniş gruplarla denendiği araştırmaların yanında, müzik eğitimi alanında bireysel ya da küçük gruplarla yürütülen derslerde de etkili olduğu söylenebilir.

$\mathrm{Bu}$ araştırmada, bilişsel alana yönelik başarı testi puanları bakımından, deney grubu ile kontrol grubu arasında deney grubunun lehine anlamlı bir fark bulunmuştur. Aynı zamanda deney grubunun bilişsel alana yönelik sontest puanlarında da önteste göre anlamlı düzeyde artş görülmüş̧ür. Bu sonuca göre, viyolonsel eğitiminde duruş ve tutuş, çalgıda teknik hâkimiyet, tempo ve ritim, entonasyon, artikülasyon, dinamik öğeler, müzikal ifade ve kavramlar bilgisini içeren, bilişsel alana yönelik davranışların kazandırılmasında dizgeli öğretimin etkili olduğu görülmektedir.

Araştırmadan elde edilen bulgulara göre, devinişsel alana yönelik performans puanları bakımından, deney grubu ile kontrol grubu arasinda deney grubunun lehine anlamlı bir fark bulunmuştur. Aynı zamanda deney grubunun devinişsel alana yönelik sontest puanları da önteste göre anlamlı düzeyde artmıştır. Bu sonuca göre, viyolonsel eğitiminde duruş ve tutuş, çalgıda teknik hâkimiyet, tempo ve ritim, entonasyon, artikülasyon, dinamik öğeler ve müzikal ifadeyi içeren devinişsel alana yönelik becerilerin kazandırılmasında dizgeli öğretimin etkili olduğu görülmektedir. Bunun yanında, öğretmen rehberliği olmadan sonteste bireysel olarak hazırlanan öğrencilerden, dizgeli öğretim yaklaşımı ile viyolonsel eğitimi alan deney grubu öğrencilerinin kendi öğrenmelerini planlayabildikleri anlaşılmaktadır. Bir başka ifadeyle, viyolonsel öğrencilerinin bireysel çalışmalarını nasıl planlayacakları ve uygulayacakları konusunda dizgeli öğretime dayalı aldıkları viyolonsel eğitimi yol gösterici olmuştur.

Müzik eğitimi alanında yapılan araştırmalarda dizgeli öğretime göre düzenlenmiş öğretim faaliyetlerinin, öğrencilerin bilgi düzeylerini arttırarak çalg1 çalmakla ilgili performans başarılarında etkili olduğu görülmektedir. Benzer şekilde, bu araştırmadan elde edilen bulgulara göre, viyolonsel eğitiminde öğrencilerin bilişsel alana yönelik öğrenme düzeylerinin, viyolonsel çalmakla ilgili performans becerilerine de yansıdığı anlaşılmaktadır. Sonuç olarak, içerik bakımından öğretim sürecinin her basamağının tüm ayrıntılarıyla planlandığı dizgeli öğretim yaklaşımının, müzik ve çalg1 eğitiminde bilişsel ve devinişsel hedeflere ulaşılmasında etkili ve kullanılabilir bir model olduğu söylenebilir.

\section{6. Öneriler}

Araştırmadan elde edilen sonuçlar doğrultusunda aşağıdaki öneriler getirilmiştir:

1. Bu araştırmadan ve dizgeli öğretimin uygulandığı diğer araştırmalardan elde edilen, dizgeli öğretimin öğrenci başarısı üzerindeki olumlu etkileri ile ilgili sonuçlara dayanarak, bu konuda uzman akademisyenler tarafindan her kademedeki müzik eğitimcilerine ve özellikle çalg1 öğretmenlerine dizgeli öğretim modeli hakkında bilgi verilebilir ve dizgeli öğretim yaklaşımının özellikleri anlatılabilir. Müzik eğitimi alanındaki bir ünitenin dizgeli öğretim modeline göre nasıl planlanacağ1 
Şen, Ç., \& Özdemir, M. A. (2017). Viyolonsel eğitimi sürecinde dizgeli öğretim modelinin öğrenci başarısına etkisi. Journal of Human Sciences, 14(4), 3009-3029. doi:10.14687/jhs.v14i4.4881

ve uygulanabileceği konusu öğretilebilir. Böylelikle müzik eğitiminde çağdaş ve farklı öğrenmeöğretme yaklaşımlarının uygulanması konusuna ilgi duyan eğitimcilerin yararlanmaları sağlanabilir.

2. Viyolonsel eğitimi dersi öğretim programları ve ders kitapları, Milli Eğitim Bakanlı̆̆’nın yenileme çalışmaları kapsamında uzman akademisyenlere görev verilerek dizgeli öğretim modeline uygun olarak yeniden düzenlenebilir.

3. Dizgeli öğretimin, müzik eğitiminin başka alanlarındaki etkililiği üzerine karşılaştırmalı olarak farklı araştırmalar yapılabilir.

4. Dizgeli öğretim ile diğer öğrenme-öğretme yaklaşımlanının etkililiğini müzik eğitiminde karşılaştırmalı olarak ölçecek araştırmalar yapılabilir.

\section{Kaynaklar}

Acat, B. (1997). Programlanderlmış eğitimin milli coğrafya öğrenci balansı üzerine etkisi. Yayınlanmamış araştırma, Ankara.

Adıgüzel, Y. (1998). İlkögretim okullar 4. smef sosyal bilgiler dersinde Ege Bölgesi konusunun arac-gereç kullamlarak ögretiminin değerlendirilmesi. Yayınlanmamış yüksek lisans tezi, Marmara Üniversitesi Eğitim Bilimleri Enstitüsü, İstanbul.

Akgül, A. (2013). Enstrüman eşlikli uygulamalarn ilkë̈gretim 6. smmf ögrencilerinin mürilk dersine yönelik bassar ve tutumlarna etkisi, Yayınlanmamış doktora tezi, Marmara Üniversitesi Eğitim Bilimleri Enstitüsü, İstanbul.

Alacapınar, G. (2001). Hayat Bilgisi ögrretiminde programlandirlmus ögrretimin erişi ve kahuclĭga etkisi. Yayınlanmamış doktora tezi, Hacettepe Üniversitesi Sosyal Bilimler Enstitüsü, Ankara.

Altınok, H. (1998). Ilkö̈gretim Fen Bilgisi dersi öğretiminde kavram haritalarmm kullanm ve ögrenci kavramsallaşmalar üzerine etkileri. Yayınlanmamış yüksek lisans tezi, Onsekiz Mart Üniversitesi Sosyal Bilimler Enstitüsü, Çanakkale.

Aslan, S. (2012). Birleștirilmis simffl okullarda dirgeli eğitimin akademik başarya ve tutuma etkisi, Yayınlanmamış yüksek lisans tezi, Fırat Üniversitesi Eğitim Bilimleri Enstitüsü, Elazığ.

Bayazıtoğlu, E. N. (1996). İlköğretim ikinci smnf Hayat Bilgisi dersinde eğitsel oyunlar, erişi ve kahcllk. Yayınlanmamış doktora tezi, Hacettepe Üniversitesi Sosyal Bilimler Enstitüsü, Ankara.

Büyüköztürk, Ş. (2001). Deneysel Desenler, Öntest-Sontest Kontrol Grubu Desen ve Veri Analiri. Ankara: Pegem A Yayincilik.

Büyüköztürk, Ş., Çakmak, E. K., Akgün, Ö. E., Karadeniz, Ş., ve Demirel, F. (2008). Bilimsel Araştırma Yöntemleri (2. Baskı). Ankara: Pegem A Yayınc1lk.

Çetin, K. (2003). Illkögrretim sekizinci smenf T.C. Inkalap Taribi ve Atatürkçülük dersi, Atatürk'’ün Hayatı ünitesinin ögretiminin diəzgeli (programlandirlmış) ögretime göre değerlendirilmesi. Yayınlanmamış yüksek lisans tezi, Abant İzzet Baysal Üniversitesi Sosyal Bilimler Enstitüsü, Bolu.

Dalkıran, E. (2006). Keman eğitiminde performansm ölçülmesi. Yayınlanmamış doktora tezi, Gazi Üniversitesi Eğitim Bilimleri Enstitüsü, Ankara.

Demirbatır, R. E. (1996). Anadolu güzel sanatlar liselerinde viyolonsel eğitimi, karşılaşılan sorunlar ve çözüm önerileri. I. Ulusal A.G.S.L. Mürike Bölümleri Semposyumu, (s.158-163). Bursa: Uludağ Üniversitesi Eğitim Fakültesi.

Duman, B. (2009). Diøgeli ögretimin ögretmen adaylarmm yansitic dïsïnme ve demokratik tutumlarma etkisi, Yayınlanmamış yüksek lisans tezi, Fırat Üniversitesi Sosyal Bilimler Enstitüsü, Elazı̆̆.

Durdukoca, Ş. F. (2013). Diəggeli eğitim ve dïz anlatım yöntemleriyle ișlenen ögretim uygulamalarmin ögrretmen adaylarmm epistemolojik inanç, ögrenme yaklaşımlar, üstbilisssel farkindallk ve akademik bașarlarna etkisi, Yayınlanmamış doktora tezi, İnönü Üniversitesi Eğitim Bilimleri Enstitüsü, Malatya.

Eakes, K. W. (2009). A comparison of a sociocultural and a chronological approach to music appreciation in face-to-face and online instructional formats. Doctoral dissertation, Auburn University, Alabama, USA.

Ekiz, D. (2003). Eg̈itimde Araștıma Yöntem ve Metodlarna Giriş: Nitel, Nicel ve Elesstirel Kuram Metodolojileri. Ankara: Anı Yayıncilik. 
Şen, Ç., \& Özdemir, M. A. (2017). Viyolonsel eğitimi sürecinde dizgeli öğretim modelinin öğrenci başarısına etkisi. Journal of Human Sciences, 14(4), 3009-3029. doi:10.14687/jhs.v14i4.4881

Eldemir, A. C. (2010). Geleneksel Türk Sanat Müziği dersinde diaggeli ögretim yönteminin ögrenci erişişine ve kahcul̆ğa etkisi. Yayınlanmamış doktora tezi. Gazi Üniversitesi Eğitim Bilimleri Enstitüsü, Ankara.

Emir, S. (2001). Sosyal Bilgiler ögretiminde yaratıc düsünmenin erişiye ve kalıcıll̆̆a etkisi. Yayınlanmamış doktora tezi, Hacettepe Üniversitesi Sosyal Bilimler Enstitüsü, Ankara.

Eroğul, G. (1997). Programlandınlmıs eğitimin öğrenci erişisi ų̈̊erine etkisi. Yayınlanmamış araştırma, Ankara.

Fidan, N. (1996). Okulda Ögrenme ve Ögrretme. Ankara: Alkım Yayınevi.

Greer, R. D. (1980). Design for Music Learning. New York: Teachers College Press.

Hargreaves, D. (1999). The developmental psychology of music: scope and aims. G. Spruce (Ed.), Teaching Music, 45-57. London: Routledge Falmer.

Hesapçığlu, M. (1998). Öğretim İlke ve Yöntemleri, Eğitim Programlar ve Ögrretim (5. Bask1). İstanbul: Beta Basın Yayım Dağıtım.

Kapıcıŏ̆lu, M. O. K. (2006). Digggeli öğretimin etkililiği. Yayınlanmamış doktora tezi, Hacettepe Üniversitesi Sosyal Bilimler Enstitüsü, Ankara.

Kayabaşı, Y. (1997). Programlandırlmıs, dünya bankası eğitim projesi ve geleneksel ögretime göre eğitim gören ögrencilerin erişi ve kahcullk düzeyleri. Yayınlanmamış doktora tezi, Hacettepe Üniversitesi Sosyal Bilimler Enstitüsü, Ankara.

Kılıç, A. (2000). İlkokuma yazma ögretiminde programlandinlmıs ögretime göre metin yönteminin etkililiği. Yayınlanmamış doktora tezi, Hacettepe Üniversitesi Sosyal Bilimler Enstitüsü, Ankara.

Kleesattel, A. L. (2012). Applications of somatic practices to cello playing and pedagogy. Unpublished doctoral dissertation, The University of Wisconsin-Madison, Wisconsin, USA.

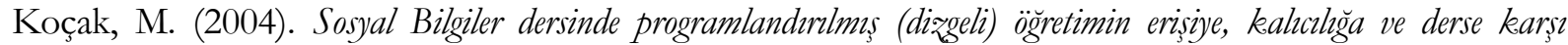
tutuma etkisi. Yayınlanmamış yüksek lisans tezi, Abant İzzet Baysal Üniversitesi Sosyal Bilimler Enstitüsü, Bolu.

Kurtuldu, M. K. (2007). Bilgiyi işleme modeline dayal piyano eğitimi’nde genel ögrenme stratejilerinin yeri ve görsel imajlar olușturma yönteminin kullanılabilirlik düzeyi. Yayınlanmamış doktora tezi. Gazi Üniversitesi Ĕ̈itim Bilimleri Enstitüsü, Ankara.

Küçükoğlu, A. (2007). Diggeli ögretimin ögrrenci erişisine etkisi. Yayınlanmamış doktora tezi, Atatürk Üniversitesi Sosyal Bilimler Enstitüsü, Erzurum.

Küpana, M. N. (2011). Müzike ögretmeni adaylarna yönelik geliștirilen piyanoda deşifre ögretimi programmmn etkililiğinin sınanması. Yayınlanmamış doktora tezi, Marmara Üniversitesi Eŭitim Bilimleri Enstitüsü, İstanbul.

Memişoğlu, H. (2003). İlköğretim okullarnda Sosyal Bilgiler dersi coğrafya konularmm öğretmenin programlandırlmış ögretime göre değerlendirilmesi. Yayınlanmamış doktora tezi, Abant İzzet Baysal Üniversitesi Sosyal Bilimler Enstitüsü, Bolu.

Otacıŏlu, S. G. (2005). Mü̊ike ögretmenliği piyano eğitimi dersi için bir model denemesi. Yayınlanmamış doktora tezi. Marmara Üniversitesi Eğitim Bilimleri Enstitüsü, İstanbul.

Öntaş, T. (2010). İlkögrretim Sosyal Bilgiler dersinde yapılandirmacr yaklaşım ile dizgeli eğitimin ögrenci erişisine etkisi arasindaki fark. Yayınlanmamış yüksek lisans tezi, Hacettepe Üniversitesi Sosyal Bilimler Enstitüsü, Ankara.

Özalemdar, L. (2013). Biyolojide uygulanan dįgeli eğitimin yaratıc düsü̈nce erişisine etkisi, Yayınlanmamış yüksek doktora tezi, Karadeniz Teknik Üniversitesi Eğitim Bilimleri Enstitüsü, Trabzon.

Özdemir, M. (2014). Mürike ögretmenlï̆i klasike gitar eğitimi dersi için eklektik bir model önerisi, Yayınlanmamış doktora tezi, Marmara Üniversitesi Eğitim Bilimleri Enstitüsü, İstanbul.

Özen, N. (2004). Çalg1 eğitiminde yararlanılan müzik eğitimi yöntemleri. Gaz̧i Üniversitesi Gaz̧i Eğitim Fakültesi Dergisi, 24(2), 57-63.

Öztürk, C. (1997). Karma yöntemin ilkögretim okulu 5. sınf Sosyal Bilgiler dersinde ögrenci erişisine etkisi (Konya ilinde bir araștırma). Yayınlanmamış yüksek lisans tezi, Gazi Üniversitesi Eğitim Bilimleri Enstitüsü, Ankara.

Paş, A. K. (2004). İlkögretim beşinci sımf Sosyal Bilgiler dersi Cumburiyete nasıl kavustuk ünitesinin ögretiminin programlandırlmıs ögretime göre değerlendirilmesi. Yayınlanmamış yüksek lisans tezi, Abant İzzet Baysal Üniversitesi Sosyal Bilimler Enstitüsü, Bolu. 
Şen, Ç., \& Özdemir, M. A. (2017). Viyolonsel eğitimi sürecinde dizgeli öğretim modelinin öğrenci başarısına etkisi. Journal of Human Sciences, 14(4), 3009-3029. doi:10.14687/jhs.v14i4.4881

Piji, D. (2006). Diそgeli ögretime göre gelistirilen eşlik dersi programmm akademik basaryya, tutuma, yeterlik algisina ve kahcalğa etkisi. Yayınlanmamış doktora tezi. Marmara Üniversitesi Eğitim Bilimleri Enstitüsü, İstanbul.

Romiszowski, A. J. (1984). Designing Instructional Systems. New York: Nichols Publishing Company.

Saraç, A. G. (1996). Türkiye'de eğitim fakülteleri mürik eğitimi bölümlerinde çalg eğitiminin bir boyutu olarak viyolonsel ögretim programlarnda belirlenen devinissel hedefler ve hedef davranıslarn gerçeklesme dereceleri. Yayınlanmamış doktora tezi, Atatürk Üniversitesi Sosyal Bilimler Enstitüsü, Erzurum.

Saraç, A. G. (2003). Öğrenme kuramlarına göre bir yaylı çalg1 olarak viyolonsel eğitimi ve viyolonsel öğretim programı süreci. Muğla Üniversitesi Sosyal Bilimler Enstitïsü Dergisi, (11), 25-37.

Senemoğlu, N. (2007). Kuramdan Uygulamaya Gelişim, Ögrenme ve Öğretim. Ankara: Gönül Yayınc1lı.

Sezginsoy, B. (2011). Sosyal bilgiler dersinde tarih bilinci olusturmada dirggeli ögretimin etkililiği, Yayınlanmamış doktora tezi, Hacettepe Üniversitesi Sosyal Bilimler Enstitüsü, Ankara.

Sıvacı, S. Y. (1997). Programlandinlmış öğretimin ögrenci erişisine etkisi ortaokul 2. sime milli coğrafya dersi örneği. Yayınlanmamış araştırma, Ankara.

Sönmez, V. (1994). Program Gelistirmede Ögrretmen El Kitabı (6. Baskı). Ankara: Pegem.

Sönmez, V. (2000). Programlandırılmış öğretimle öğretmen yetiştirme. Eğitim Araștırmalar, 1, 60-67.

Sönmez, V. (2003). Dizgeli eğitimle sınıf ortamında doğrudan demokrasi. Eğitim Araşstrmalar, 11, 64-72.

Sönmez, V. (2004). Diøgeli Eğitim. Ankara: Anı Yayıncilık.

Şahinkesen, A. (1990). Sistem yaklaşımı, analiz ve program hazırlama. Ankara Üniversitesi Ë̆gitim Bilimleri Fakültesi Dergisi, 23 (2), 645-676.

Takkaç, A. (2007). Dį̊geli eğitimin Sosyal Bilgiler dersinde 5. smme ögrencilerinin erişilerine etkisi. Yayınlanmamış yüksek lisans tezi, Hacettepe Üniversitesi Sosyal Bilimler Enstitüsü, Ankara.

Toklucu, S. K. (2013). Issbirliğine dayal ögrenme yöntemi ile diageli eğitimin 4. simf sosyal bilgiler dersinde bassaryya, kahcolğga ve tutuma etkisinin karşslaştırlması, Yayınlanmamış yüksek lisans tezi, Ahi Evran Üniversitesi Sosyal Bilimler Enstitüsü, Kırşehir.

Uçan, A. (1994). Mü̈ike Eğitimi: Temel Kavramlar-ilkeler-Yaklaşımlar. Ankara: Müzik Ansiklopedisi Yayinları.

Varış, F. (1998). Eğitim Bilimine Giriş, İstanbul: Alkım Yayınları.

Yağışan, N. (2008). Keman Calmanm Biomekanik Analiæi, Konya: Eğitim Kitabevi Yayınları.

Yokuş, H. (2009a). Piyano eğitiminde ögrenme stratejilerinin kullamlmasma yönelik etkinliklerin performans başarısina ve üstbilişsel farkendalğga etkisi. Yayınlanmamış doktora tezi, Marmara Üniversitesi Eğitim Bilimleri Enstitüsü, İstanbul.

Yokuş, T. (2009b). Gitar eğitiminde üstbilissel becerilerin geliștirilmesine yönelike etkinliklerin performans basarssma etkisi. Yayınlanmamış doktora tezi. Marmara Üniversitesi Eğitim Bilimleri Enstitüsü, İstanbul.

Yokuş, H. ve Yokuş, T. (2010). Mürịk ve Calgı Öğrenimi İ̧in Strateji Rebberi I. Ankara: Pegem Akademi.

\section{Extended English Abstract}

\section{Problem and purpose}

Systematic teaching method is a model proposed by Veysel Sönmez in 1982 and lesson plans were created and implemented in accordance with it and it was evaluated and improved after each implementation. Systematic teaching method, developed by combining village institutes model, mastery learning approach, information processing model, computer-assisted teaching, philosophy of possibility and teaching practices, was experimented in post-graduate dissertations, some researches, at various schools and lessons. It is a synthesis model where education is constructed in accordance with systematic approach and philosophy of possibility, all theories, strategies, methods and techniques are implemented when appropriate, learning environments are planned accordingly and maximum student participation is aimed. Besides facilitating teaching for teachers, it enables making improvements by revising the system through feedbacks and, therefore, results in changes in students' terminal behaviours to a large extent. 
Şen, Ç., \& Özdemir, M. A. (2017). Viyolonsel eğitimi sürecinde dizgeli öğretim modelinin öğrenci başarısına etkisi. Journal of Human Sciences, 14(4), 3009-3029. doi:10.14687/jhs.v14i4.4881

The achievement of education process is related with planning the teaching process in a qualified way to a large extent. An important gain of systematic teaching is that it reveals all the details of the steps of the teaching process.

Research in this field reveals that supervising education by means of systematic approach both saves time and labour and provides benefit for the process of the system.

Studies on the effectiveness of teaching methods in instrumental education that is a branch of music education will certainly contribute to creating more effective teaching-learning environments and developing more functional teaching programmes. This study is based on a need of this kind in violoncello education, a branch of instrumental education. In accordance with these ideas, the question how violoncello lessons can be more effective for both students and teachers was the starting point of this study. Thus, a violoncello education lesson plan based on systematic method, where each step of instruction is planned in line with educational sciences philosophies and which facilitates teaching for students and learning for students was developed in this study.

This study aimed to examine the effect of the use of systematic teaching method in fine arts high school violoncello education lessons on students' academic success in terms of cognitive and psychomotor skills.

\section{Method and material}

In this study, the pretest-posttest control group experimental pattern was used and the study was carried out with a sample of violoncello students $(\mathrm{N}=14)$ who were first, second and third graders at Bursa Zeki Müren Fine Arts High School in spring term in 2009-2010 academic year.

Music departments of Fine Arts High schools comprise of four classes, each of which has 30 students. At the very beginning, the instruments that students will be playing are distributed to students by taking the quota into consideration. When this general distribution is examined, it can be seen that every year an average of 3-5 students are selected to play violoncello. While this study was being conducted, there was no fourth grade students studying violoncello at this school. Therefore, a total of 14 students who were studying at first, second and third grades were involved in this study.

In the scope of this study, a syllabus for 8 weeks (16 hours) was prepared based on systematic teaching method so as to improve the cognitive and psychomotor learning levels of the violoncello students.

According to the results of the pre-test, one experimental $(n=7)$ and one control group $(n=7)$ were formed randomly and equivalently.

Whereas the experimental group was applied a syllabus based on systematic teaching for 8 weeks ( 16 hours) by the researcher, the control group was applied the traditional method which was being used at school by the other violoncello teacher. At the end of the implementation period, both experimental and control groups were re-measured by data collection instruments to obtain the data of the post-test.

In order to gain the data, two scales were developed by the researcher aimed at cognitive field and psychomotor field.

"Violoncello Lesson Cognitive Field Assessment Test" was applied to a total of 70 string instrument students studying at this school to test its validity and reliability. The reliability of the test was measured by Cronbach Alpha statistical test. At first, the test was composed of 65 items; however, after the item analysis 4 items were removed and the result of the test showed that it was highly reliable. The cognitive field assessment test was applied to groups before and after the implementation.

"Violoncello Lesson Performance Assessment Test" was applied to groups before and after the implementation. Five observers did assessments to obtain the data of this scale. Each observer graded the students in accordance with the items in the scale by observing and hearing students' 
Şen, Ç., \& Özdemir, M. A. (2017). Viyolonsel eğitimi sürecinde dizgeli öğretim modelinin öğrenci başarısına etkisi. Journal of Human Sciences, 14(4), 3009-3029. doi:10.14687/jhs.v14i4.4881

performances and in an independant way. Students' performances during pre-test and post-test were recorded using camcorder.

The consistency of the grades given to the students by the observers during pre-test and post-test was identified by Spearman Brown Rank Order Correlation Coefficient. According to the statistical results, it was seen that the grades given to the students by the observers were consistent and there was no significant difference among observers in terms of statistics.

Statistical analysis was utilized to analyse the data obtained from pre-test and post-test. Mann Whitney-U Test was used to identify the equivalence of the experiment and control groups before the implementation and the difference between post-test scores after the implementation. Wilcoxon Signed Rank Test was used to identify the improvement of both experimental and control groups.

\section{Results and recommendations}

In accordance with the data gained from the research, the findings can be summarized as the following:

1. A significant difference in favour of the experimental group was found between the cognitive field knowledge levels of the experimental group who received systematic model teaching and control group who received traditional teaching.

2. A significant difference in favour of the experimental group was found between the psychomotor field performance levels of the experimental group who received systematic model teaching and control group who received traditional teaching.

The results show that violoncello lessons structured in line with systematic teaching approach are effective in improving not only students' knowledge levels but also skill levels in terms of performance.

The following recommendations can be offered for related research: Based on the results of this study and other studies related to positive effects of the systematic teaching approach on students' success, it is recommended that academicians inform music educators at all levels and especially instrument teachers about systematic teaching method and its characteristics. They can teach music educators how to plan and implement a unit in music and instrumental education in accordance with systematic teaching method. In-service seminars can be organized for music educators about planning the musical education process, conducting teaching activities, philosophies, models, strategies, methods and techniques that can be applied, clues, feedbacks, corrections, motivation, reinforcers and when, where and how to use them. Instrument teachers can be trained by the academicians in the field about selecting and using the appropriate strategies, methods and techniques. Teaching methods can be defined for which sequence of actions to follow for gaining which skills in violoncello education. Comparative studies can be carried out on the effectiveness of systematic teaching approach on other fields in music education. In addition, some comparative studies can be done to compare the effectiveness of systematic teaching approach and other teaching methods in music education. 